\title{
Dolomitization Controlled by Paleogeomorphology in the Epicontinental Sea Environment: A Case Study of the 5th Sub-Member in 5 Member of the Ordovician Majiagou Formation in Daniudi Gas Field, Ordos Basin
}

\author{
Yilin Li ${ }^{1}$ (D), Wang Xu ${ }^{1,2, *}$, Meiyan Fu ${ }^{1,2}$, Hucheng Deng ${ }^{1,2}$, Dong Wu ${ }^{1,2}$, Jianhua He ${ }^{1,2}$, Hengwei Guo ${ }^{1}$ \\ and Pei Chen ${ }^{1}$
}

1 College of Energy, Chengdu University of Technology, Chengdu 610059, China; liyilin@stu.cdut.edu.cn (Y.L.); fumeiyan08@cdut.cn (M.F.); denghucheng@cdut.cn (H.D.); wudong19@cdut.edu.cn (D.W.); hejianhua19@cdut.edu.cn (J.H.); 2018050111@stu.cdut.edu.cn (H.G.); 2019050105@stu.cdut.edu.cn (P.C.)

2 State Key Laboratory of Oil and Gas Reservoir Geology and Exploitation, Chengdu University of Technology, Chengdu 610059, China

* Correspondence: xuwang19@cdut.edu.cn; Tel.: +86-187-1979-9283

check for

updates

Citation: Li, Y.; Xu, W.; Fu, M.; Deng, H.; Wu, D.; He, J.; Guo, H.; Chen, P. Dolomitization Controlled by

Paleogeomorphology in the

Epicontinental Sea Environment: A Case Study of the 5th Sub-Member in 5 Member of the Ordovician Majiagou Formation in Daniudi Gas Field, Ordos Basin. Minerals 2021, 11, 827. https://doi.org/10.3390/ $\min 11080827$

Academic Editors:

Katarzyna Jarmołowicz-Szulc,

Leszek Marynowski and

Peter Modreski

Received: 18 June 2021

Accepted: 23 July 2021

Published: 30 July 2021

Publisher's Note: MDPI stays neutral with regard to jurisdictional claims in published maps and institutional affiliations.

Copyright: (c) 2021 by the authors. Licensee MDPI, Basel, Switzerland. This article is an open access article distributed under the terms and conditions of the Creative Commons Attribution (CC BY) license (https:// creativecommons.org/licenses/by/ $4.0 /)$.
Abstract: The 5th sub-member in 5 Member Ordovician Majiagou Formation in Daniudi Gas Field, Ordos Basin, is deposited in an environment consisting of an ancient epicontinental sea, where very fine crystalline dolostone reservoir has developed. In this study, based on the petrological and geochemical characteristics, the genesis of the dolomite developed in $\mathrm{M}_{5}{ }^{5}$ were studied by analyzing the properties and sources of the dolomitization fluids, and the influence of the paleogeomorphology differences on the distribution of dolostone was also discussed in order to clarify the distribution of the dolostone developed in the lime flat of the epicontinental sea. The dolostone of the $\mathrm{M}_{5}{ }^{5}$ had a crystal structure, mainly including microcrystalline and very fine crystalline. The content of $\mathrm{MgO}$ and $\mathrm{CaO}$ in dolomite was negatively correlated, indicating that it was the result of replacement. The dolomite was dark red under cathode luminescence, and the distribution mode of rare earth elements showed the negative anomaly of $\mathrm{Ce}$ and $\mathrm{Eu}$, indicating that the dolomitization fluid was sea-sourced fluid. The $\delta^{13} \mathrm{C}, \delta^{18} \mathrm{O}$, and ${ }^{87} \mathrm{Sr} /{ }^{86} \mathrm{Sr}$ isotope range of limestone was similar to that of Ordovician seawater in the study area, whereas the $\delta^{13} \mathrm{C}, \delta^{18} \mathrm{O}$, and ${ }^{87} \mathrm{Sr} /{ }^{86} \mathrm{Sr}$ of dolostone were obviously more positive than that of limestone. The substitute index of the salinity $(Z)$ of the dolomitization fluid was higher than 122 , which is higher than limestone $(Z=120.5)$, indicating that the dolomitization fluid was slightly evaporated seawater. The wormholes observed on the core and the gypsum in the penecontemporaneous period observed in the thin sections indicated that the dolostone was formed in a period when the sea level was relatively low, and it was the result of seepage-reflux dolomitization. By analyzing the correlation between the thickness of dolostone and the paleogeomorphology of the $\mathrm{M}_{5}{ }^{5}$ of the sedimentary period, it was found that the thickness of dolostone at relatively high altitude was significantly larger than that of other areas. The development of dolostone was controlled by sea level, and the local paleogeomorphology controls the distribution of dolostone during the period of low sea level. There were many more limestone-dolostone cycles and larger cumulative thicknesses of dolostone at relatively higher topography. This study provides a theoretical basis for the prediction of the distribution of dolostone reservoirs in the carbonate tidal flat environment dominated by lime flats under the background of the ancient epicontinental sea.

Keywords: Ordos Basin; Majiagou Formation in Ordovician; epicontinental sea; dolomitization; paleogeomorphology

\section{Introduction}

Dolostone, as an important oil and gas reservoir rock, accounts for more than half of carbonate reservoirs [1-3]. In order to better predict the distribution of dolostone reservoirs, 
geologists have long been focusing on the study of the dolomitization mechanism and many achievements have been accomplished such as the penecontemporaneous sabkha model [4-6] and the seepage-reflux model under an evaporation environment [7-9], which are used to explain the genesis of island dolostone [10-12], the hydrothermal fluid model related to hydrothermal solution [13-15], the fault-controlled model of the combination of hydrothermal or formation fluid [16-18], and the intermediate-deep burial dolomitization with large burial depth, which is often accompanied by hydrothermal development $[19,20]$. These dolomitization models explain the origin of dolomite from different sources and the dynamics of magnesium-enriched fluids, and they have played an important role in the prediction of dolostone reservoirs.

The Daniudi Gas Field is a large-scale commercial gas reservoir in the Ordos Basin, Northwest China. The coal seams and mudstones of the Upper Paleozoic and the argillaceous carbonate rocks of the Majiagou Formation provide sufficient gas sources for the Daniudi [21-23]. The sedimentary of the 5th sub-member in 5 Member of the Ordovician Majiagou Formation $\left(\mathrm{M}_{5}^{5}\right)$ in Daniudi area is mainly limestone, but there are multiple layers of dolostone developed locally, with a large cumulative thickness and desirable physical properties [24]. The $\mathrm{M}_{5}{ }^{5}$ reservoir in the study area is mainly composed of intercrystalline pores in dolostone. The average porosity is $5.25 \%$, and the maximum is $10.3 \%$. The maximum permeability without cracks is $4.07 \mathrm{mD}$. The physical properties of very fine crystalline dolostone are better than microcrystalline dolostone. Therefore, a large amount of research on the genesis of dolomite in the $\mathrm{M}_{5}{ }^{5}$ has been conducted including the penecontemporaneous sabkha model, seepage-reflux model, and intermediate-deep burial dolomitization. For the very fine crystalline dolostone with good storage capacity, predecessors have also proposed a dolomitization model with shallow burial and mixed water [25-27]. However, at present, there is no unified conclusion on the cause of dolomite, and distribution of dolostone is still poorly understood [28-32]. Some scholars propose that the thickness of dolostone in the study area has a better coupling with paleokarst landform, and the dolomitization and distribution in this area is controlled by paleokarst landform [33]. On this basis, the dolomitization model of atmospheric freshwater origin is applied to explain its origin [34-36]. However, there is no direct evidence for the above view. Actually, without sufficient research on the fluid properties and sedimentary environment, it is difficult to analyze the genesis and distribution of dolostone based only on the background of the karst modification in the study area and the coupling of the paleokarst landform and the distribution of dolostone. In addition, it is also considered that the distribution of dolostone may be controlled by changes in sea level [37-40]. However, no study has been performed on the rules of the plane and spatial distribution of dolostone reservoirs. Therefore, on the basis of previous studies, this study focused on clarifying the origin of dolomitization, examining the conditions for the development of very fine crystalline dolostone, and exploring the distribution characteristics and main controlling factors of dolostone.

In this study, based on the lithological characteristics and depositional environment, the properties of dolomitization fluid are discussed applying isotopic and elemental geochemical data. Combined with the degree of order in dolomite and cathodoluminescence results, the origin of dolomitization was analyzed. According to the thin section observation and core observation results and X-ray diffraction (XRD) results, the thickness of the dolostone in each well was counted, and the paleogeomorphology conditions were superimposed to obtain the distribution of dolostone. The suitable dolomitization model was established to provide a basis for the next exploration in the study area and expand the theory of dolostone distribution in the epicontinental sea environment.

\section{Geological Setting}

The Ordos Basin, located in Northwestern China on the western edge of the North China Platform, is the second largest basin in China. As a polycyclic craton basin, its internal structure is relatively simple $[30,41,42]$. The interior of the Ordos Basin can be divided 
into six primary structural units: the Yishan Slope, Tianhuan Depression, West Margin Thrust Belt, Weibei Uplift, Yimeng Uplift, and Jinnxi Fault-Fold Belt [27,43] (Figure 1). The study area is the Majiagou Formation in Daniudi, Yulin, northeast of the Yishan Slope. The Majiagou Formation is the Paleozoic Ordovician strata, which corresponds to the Floian, Dapingian, and Darriwilian in the international strata. The Majiagou Formation in the Ordos Basin can be divided into six members from $M_{1}$ to $M_{6}$, of which the $M_{5}$ member can be subdivided into $\mathrm{M}_{5}{ }^{1}$ to $\mathrm{M}_{5}{ }^{10}$ (Figure 2) [27,44-46]. The Ordovician Majiagou sedimentary period was a shallow carbonate platform environment, mainly developing tidal flat facies and shoal facies deposits. During this period, there were three transgressionregression processes in which the $\mathrm{M}_{1}, \mathrm{M}_{3}$, and $\mathrm{M}_{5}$ deposited were transgression periods, and the $\mathrm{M}_{2}, \mathrm{M}_{4}$, and $\mathrm{M}_{6}$ deposited were regression periods, with mainly carbonate rocks and a small amount of evaporite $[43,47,48]$. Due to the multi-period and long-term karst transformation in the later period, the $\mathrm{M}_{6}$ is sporadically distributed in the study area [49]. The predecessors had different understandings of the sequence boundary of the study area. It is generally believed that the $\mathrm{M}_{5}$ sedimentary period was in the transgressive period during regression $[38,39,50]$. In the study area, the sedimentary period from $M_{1}$ to $M_{3}$ developed evaporative platform subfacies, the $\mathrm{M}_{4}$ deposited in open platform subfacies, the $\mathrm{M}_{5}$ deposited in restricted platform subfacies, and the $\mathrm{M}_{6}$ were missing due to the fact of denudation. The $\mathrm{Ma}_{5}{ }^{5}$ deposited in the period of transition from a restricted platform to an open platform and then back to a restricted platform. During this period, ancient climate changes and sea-level turbulence changes with lime flat developed during the transgression period, and dolomitic flat developed during regression, mainly developed microcrystalline limestone and gray-yellow dolostone [27,30,43].
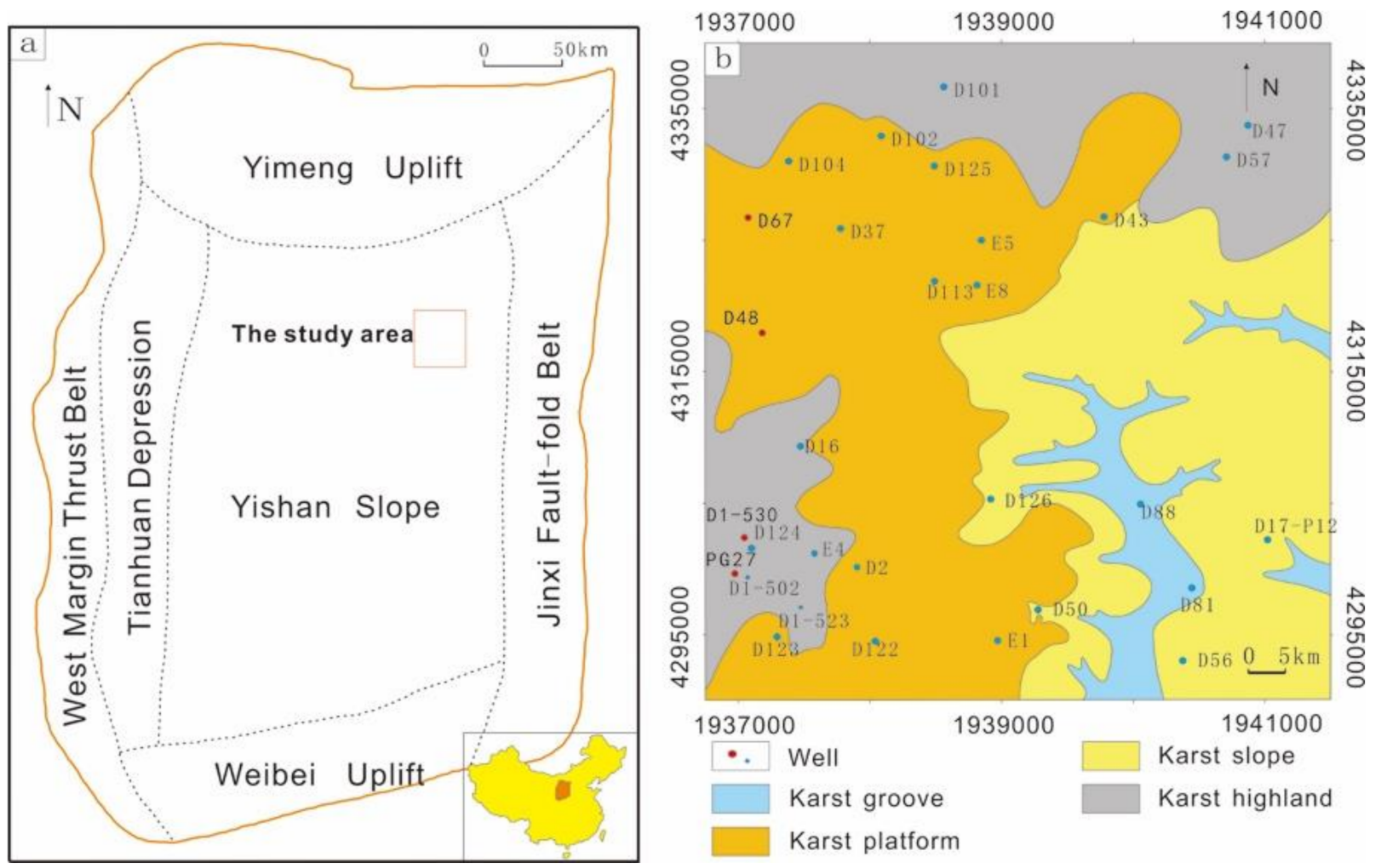

Figure 1. Location of the study area and distribution of wells at the Ordovician Majiagou Formation in the Daniudi area, Ordos Basin: (a) location and structural division of the Ordos Basin; (b) well location and paleokarst landform in Daniudi Gas Field. 


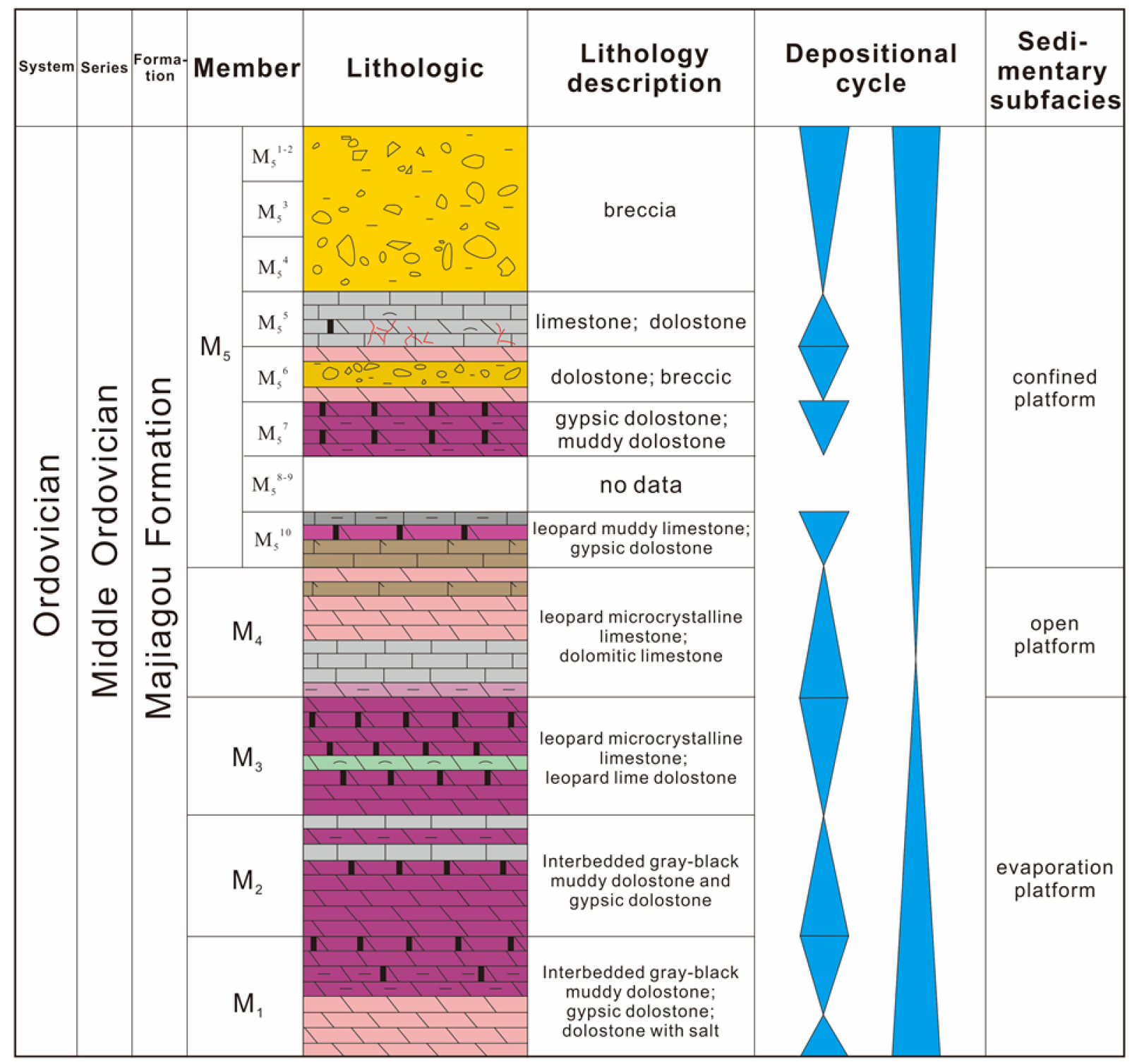

Figure 2. Stratigraphic and sedimentary characteristics of the Ordovician Majiagou Formation in the Daniudi area, Ordos Basin [38].

\section{Materials and Methods}

In order to discuss the genesis of dolomitization and its distribution in the Ordovician, Majiagou Formation, samples were collected from the wells D48, D1-530, PG27, D67, and D30 (Figure 1). A total of 18 samples of the $\mathrm{M}_{5}$ member dolostone and limestone were collected. To ensure the accuracy of analytic results, the collected samples were all fresh and organic poor. Thin section observations were performed on all samples, and typical samples were selected for geochemistry and C, O, and Sr isotope analyses (Table 1). Analyses of major and trace elements, C, O, and Sr isotope were carried out at the State Key Laboratory of Oil and Gas Reservoir Geology and Exploitation (Chengdu University of Technology). 
Table 1. The sample information and test items in the study.

\begin{tabular}{|c|c|c|c|c|c|c|c|c|c|}
\hline $\begin{array}{l}\text { Sample } \\
\text { Number }\end{array}$ & Well & Depth (m) & Lithology & CL & Section & XRD & $\begin{array}{l}\text { Stable } \\
\text { Isotope }\end{array}$ & $\begin{array}{l}\text { Major } \\
\text { element }\end{array}$ & $\begin{array}{c}\text { Trace } \\
\text { Element }\end{array}$ \\
\hline S1 & D67 & 2892.28 & Microcrystalline limestone & & $\sqrt{ }$ & $\sqrt{ }$ & $\sqrt{ }$ & $\sqrt{ }$ & $\sqrt{ }$ \\
\hline S2 & D1-530 & 3097.42 & Very fine crystalline dolostone & & & $\sqrt{ }$ & $\sqrt{ }$ & $\sqrt{ }$ & $\sqrt{ }$ \\
\hline S3 & D1-530 & 3101.42 & Microcrystalline dolostone & $\sqrt{ }$ & $\sqrt{ }$ & $\sqrt{ }$ & $\sqrt{ }$ & $\sqrt{ }$ & $\sqrt{ }$ \\
\hline S4 & D1-530 & 3102.96 & Microcrystalline dolostone & & $\sqrt{ }$ & & $\sqrt{ }$ & & \\
\hline S5 & D1-530 & 3102.99 & Very fine crystalline dolostone & & $\sqrt{ }$ & & $\sqrt{ }$ & & \\
\hline S6 & D1-530 & 3105.53 & Microcrystalline dolostone & $\sqrt{ }$ & & & $\sqrt{ }$ & & \\
\hline S7 & D1-530 & 3106.75 & Microcrystalline dolostone & & & $\sqrt{ }$ & $\sqrt{ }$ & $\sqrt{ }$ & \\
\hline S8 & D1-530 & 3108.28 & Microcrystalline dolostone & & $\sqrt{ }$ & $\sqrt{ }$ & $\sqrt{ }$ & $\sqrt{ }$ & $\sqrt{ }$ \\
\hline S9 & D1-530 & 3112.78 & Microcrystalline dolostone & & $\sqrt{ }$ & $\sqrt{ }$ & $\sqrt{ }$ & $\sqrt{ }$ & $\sqrt{ }$ \\
\hline S10 & D1-530 & 3115.62 & Microcrystalline dolostone & & & $\sqrt{ }$ & $\sqrt{ }$ & $\sqrt{ }$ & $\sqrt{ }$ \\
\hline S11 & D48 & 3009.32 & Microcrystalline dolostone & & & $\sqrt{ }$ & $\sqrt{ }$ & $\sqrt{ }$ & $\sqrt{ }$ \\
\hline S12 & D48 & 3013.00 & Microcrystalline dolostone & & & $\sqrt{ }$ & $\sqrt{ }$ & $\sqrt{ }$ & $\sqrt{ }$ \\
\hline S13 & D48 & 3016.00 & Microcrystalline limestone & & & & $\sqrt{ }$ & & \\
\hline S14 & D48 & 3017.99 & Microcrystalline dolostone & & & & $\sqrt{ }$ & & \\
\hline S15 & D48 & 3020.38 & Microcrystalline limestone & & $\sqrt{ }$ & & $\sqrt{ }$ & & \\
\hline S16 & D48 & 3026.35 & Microcrystalline limestone & & & $\sqrt{ }$ & $\sqrt{ }$ & $\sqrt{ }$ & \\
\hline S17 & PG27 & 2979.52 & Microcrystalline dolostone & $\sqrt{ }$ & $\sqrt{ }$ & $\sqrt{ }$ & $\sqrt{ }$ & $\sqrt{ }$ & $\sqrt{ }$ \\
\hline S18 & PG27 & 2987.35 & Very fine crystalline dolostone & & $\sqrt{ }$ & $\sqrt{ }$ & $\sqrt{ }$ & $\sqrt{ }$ & $\sqrt{ }$ \\
\hline
\end{tabular}

$\sqrt{ }$-Complete test samples.

\subsection{Cathodoluminescence}

Analysis of cathodoluminescence (CL) was completed with the CITL/CL8200MK5-2 (British) CL instrument. CL detection used the CL8200MK5 CL microscope with a 12 15 kV beam and a current intensity of $420 \sim 430 \mathrm{~mA}$ on the non-stained halves of thin sections, and the exposure time was approximately $10 \mathrm{~s}$. Then, the luminescence was recorded and the images were collected.

\subsection{Carbon and Oxygen Isotopes}

The MAT-253 stable isotope ratio mass spectrometer from Thermo Science, Waltham, MA, USA, was used to determine the overall stable carbon and oxygen isotopes of 18 carbonate rocks from 4 wells. All isotope data are expressed by the international standard material Pee Dee Belemnite (V-PDB). The samples were processed by the phosphoric acid method. The measurement accuracy of ${ }^{13} \mathrm{C}$ and ${ }^{18} \mathrm{O}$ is $0.0037 \%$.

\subsection{Strontium Isotope}

The Sr isotope of the 18 samples were analyzed with the thermal Triton Plus thermal ionization mass spectrometer. Fresh samples were crushed to $200 \mathrm{mesh}$, and then $100 \mathrm{mg}$ of the powder was placed into a beaker containing $0.8 \mathrm{~mol} / \mathrm{L}$ of hydrochloric acid. The centrifuged clear liquid was separated and purified by an ion exchange column equipped with AG50W-W8 resin. Using hydrochloric acid as the eluent, pure Sr was separated and then tested on the VG354 isotope mass spectrometer. The international standard for ${ }^{87} \mathrm{Sr} /{ }^{86} \mathrm{Sr}, \mathrm{NBS} 987$, gave a ratio of $0.710284 \pm 10(n=20,2 \sigma)$ for static analysis. All strontium ratios were corrected to a value for the standard of 0.710250 . Blank values were in the region of $0.8 \times 10^{-9} \mathrm{~g}$. The experimental error was less than $0.01 \%$.

\subsection{Major and Trace Elements}

Perkin-Elmer's Optima $5300 \mathrm{~V}$ inductively coupled plasma-atomic emission spectrometer (ICP-AES) and inductively coupled plasma mass spectrometry (ICP-MS) were used to determine the composition of elements in carbonate rocks. The sample was ground first, then passed through a 100 -mesh sieve and dried at $80{ }^{\circ} \mathrm{C}$ for $5 \mathrm{~h}$. Next, $100 \mathrm{mg}$ of the sample was dissolved in a mixed solution consisting of $4 \mathrm{~mL}$ of hydrofluoric acid, $3 \mathrm{~mL}$ of nitric acid, $2 \mathrm{~mL}$ of hydrochloric acid, $1 \mathrm{~mL}$ of perchloric acid, and 3 drops of sulfuric acid, and heated to $200^{\circ} \mathrm{C}$ for approximately $4 \mathrm{~h}$ until white eyes appeared. Then, $5 \mathrm{~mL}$ of chloroazo acid was added to the solution to extract the elements. Finally, the solution was transferred to a $50 \mathrm{~mL}$ volumetric flask and diluted with deionized water. Finally, the 
ICP-AES method was used to determine the major elements, and the ICP-MS method was used to determine the trace elements. The experimental error was less than $5 \%$.

\subsection{X-ray Diffraction}

The mineral composition of 12 samples was measured using the DMAX-3C X-ray diffractometer $(40 \mathrm{kV}, 20 \mathrm{~mA})$ from Rigaku Corporation. The angular accuracy was greater than $0.02^{\circ}(2 \theta)$, the scanning speed was $0.05 \mathrm{~s} / \mathrm{step}$, and the scanning range was $3 \sim 50^{\circ}(2 \theta)$. We used JADA5.0 software for the semi-quantitative phase analysis. When the mineral content was greater than $40 \%$, the relative deviation was less than $10 \%$. The degree of order of dolomite was calculated by the ratio of the two diffraction peaks $d(015) / d(110)$.

\section{Results}

\subsection{Petrology}

According to the observation results of the core and thin sections, dolostone and limestone were mainly developed in the study area. Dolostone and limestone had a crystal structure. Most gypsum was completely dissolved to form dissolution pores of anhydrite, and only a small part was not dissolved. The cement was mainly calcite, and the muddy cement could be seen locally. According to this study, three types of lithology were divided, including microcrystalline limestone, microcrystalline dolostone, and very fine crystalline dolostone.

\subsubsection{Microscopic Features}

The volume of microcrystalline dolomite was approximately $42 \%$. The microcrystalline dolomite crystals were mainly other-shaped and semi-automorphic, and the crystal size was generally less than $0.03 \mathrm{~mm}$ (Figure 3a). It could be seen that the small tuberculosis of anhydrite was replaced by calcite, and pyrite was scattered sporadically. Algae laminae were observed, and the algae laminae retained the original sedimentary structure. Under $\mathrm{CL}$, the mud microcrystalline dolomite was dark red overall (Figure 3e).

Very fine crystalline dolomite accounted for approximately $10 \%$. Powder crystalline dolomite was mainly semi-automorphic-automorphic, with a crystal size of $0.03 \sim 0.1 \mathrm{~mm}$ (Figure 3b). Under the microscope, it could be seen that the early diagenetic stylolite cut the dolomite grains. The color of the very fine crystalline dolomite was also darker under CL.

Microcrystalline calcite accounted for approximately $45 \%$ of the total volume. It was red under the microscope by staining with Alizarin red. $\mathrm{M}_{5}$ limestone was mainly composed of crystal limestone, with very few granular limestones. The crystal size of calcite was less than $0.03 \mathrm{~mm}$, and mainly composed of microcrystalline (Figure 3c).

\subsubsection{X-ray Diffraction}

As shown in Table 2, the main mineral component of dolostone in this area was dolomite, with a content of more than $95 \%$. In addition, there were few calcites, terrigenous quartz, and feldspar. Quartz was found in all samples, whereas the content was generally less than one percent. Feldspar occurred only in some samples, with the content less than $0.5 \%$. In addition, there were scattered pyrites with a content of mostly less than $0.5 \%$. Limestone was dominated by calcite, with a content generally above $98 \%$. A small amount of dolomite and quartz were also detected. The degree of order in dolomite was higher than 0.8 , and the highest value was 0.91 . The degree of order in microcrystalline dolomite ranged from 0.63 to 0.88 , mostly from 0.75 to 0.85 . 

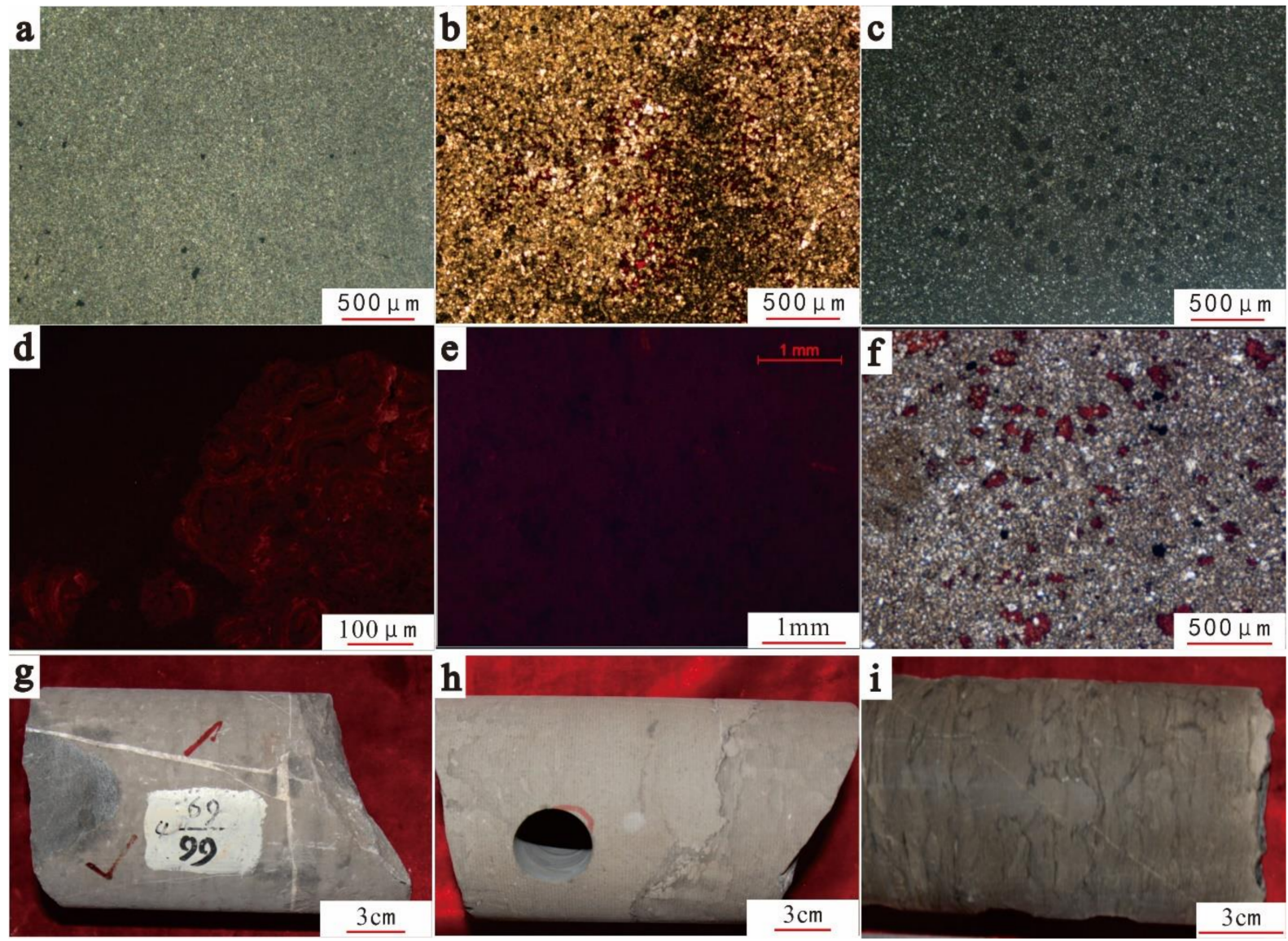

Figure 3. Microscopic characteristics and core observations of carbonate rocks in $\mathrm{M}_{5}{ }^{5}$ of the Daniudi Gas Field, Ordos Basin. (a) D37, 2926.91, m-microcrystalline dolostone; (b) D1-530, 3107.28, m—very fine crystalline dolostone; (c) D48, 3024.95, m-microcrystalline limestone; (d) PG27, 2979.52, m-calcite cement characteristics under CL; (e) D48, 3023.54, m-dolomite characteristics under CL; (f) D48, 3013, m-tuberculosis of anhydrite are replaced by calcite; (g) D48, 3020.48, m-filling calcite in cracks; (h) PG27, 2987.1, m—wavy bedding; (i) D30, 3017.5, m—wormhole.

Table 2. XRD data of the $\mathrm{M}_{5}{ }^{5}$ from the Daniudi Gas Field in the Ordos Basin.

\begin{tabular}{|c|c|c|c|c|c|c|c|c|c|c|c|c|}
\hline \multirow{2}{*}{$\begin{array}{l}\text { Sample } \\
\text { Number }\end{array}$} & \multirow{2}{*}{ Well } & \multirow{2}{*}{ Depth (m) } & \multirow{2}{*}{ Lithology } & \multicolumn{9}{|c|}{ XRD (\%) } \\
\hline & & & & Qtz & P1 & Ha & Gy & Dol & Cal & Py & Calys & Degree of Orde \\
\hline S1 & D67 & 2892.28 & Microcrystalline limestone & 1.1 & - & - & - & - & 98.8 & 0.1 & - & / \\
\hline S2 & D1-530 & 3097.42 & Very fine crystalline dolostone & 1.2 & - & - & - & 96.6 & 2.2 & - & - & 0.91 \\
\hline S3 & D1-530 & 3101.42 & Microcrystalline dolostone & 0.8 & - & - & - & 89.3 & 9.9 & - & - & 0.88 \\
\hline S7 & D1-530 & 3106.75 & Microcrystalline dolostone & 4.7 & - & - & - & 89.2 & 0.3 & 0.6 & 5.2 & 0.63 \\
\hline S8 & D1-530 & 3108.28 & Microcrystalline dolostone & 0.3 & - & - & - & 96.1 & 3.5 & 0.1 & - & 0.83 \\
\hline S9 & D1-530 & 3112.78 & Microcrystalline dolostone & 0.6 & 0.4 & - & - & 93.9 & 5.2 & - & - & 0.74 \\
\hline $\mathrm{S} 10$ & D1-530 & 3115.62 & Microcrystalline dolostone & 0.5 & 0.3 & - & - & 94.3 & 4.6 & 0.2 & - & 0.79 \\
\hline S11 & D48 & 3009.32 & Microcrystalline dolostone & 0.3 & - & - & - & 66.2 & 33.5 & - & - & 0.79 \\
\hline S12 & $\mathrm{D} 48$ & 3013.00 & Microcrystalline dolostone & 0.4 & - & - & - & 59.0 & 40.6 & - & - & 0.80 \\
\hline S16 & D48 & 3026.35 & Microcrystalline limestone & 0.7 & - & - & - & 5.60 & 93.7 & - & - & / \\
\hline S17 & PG27 & 2979.52 & Microcrystalline dolostone & 0.8 & 0.4 & - & - & 96.3 & 2.4 & - & - & 0.83 \\
\hline S18 & PG27 & 2987.35 & Very fine crystalline dolostone & 0.2 & 0.4 & - & - & 97.4 & 2.0 & - & - & 0.83 \\
\hline
\end{tabular}

- Below the analytical detection limit. Qtz-Quartz; Pl—plagioclase; Ha—halite; Gy—gypsum; Dol—dolomite; Cal—calcite; Py-pyrite; Calys-clay minerals. /—Untested samples.

\subsection{Characteristics of Carbon, Oxygen, and Strontium}

According to previous studies, the range of carbon and oxygen isotope values of seawater in the study area varied at a range of $0.5 \%$ $-2.0 \%$ and $-7.0 \%$ o $-10.0 \%$, respectively $[1,51,52]$. The isotopic compositions of carbon, oxygen, and strontium are shown in 
Table 3. By comparing the results of this experiment with the isotope values of Ordovician seawater, the $\delta^{18} \mathrm{O}$ values in the study area were all negative, and the $\delta^{13} \mathrm{C}$ values were similar to the seawater values of the same period. The isotopic characteristics of different lithologies were different to a certain extent. The $\delta^{13} \mathrm{C}$ values of limestone samples were between $-0.46 \%$ and $-1.94 \%$, with an average value of $-0.95 \%$, and the $\delta^{18} \mathrm{O}$ values were between $-8.29 \%$ and $-11.1 \%$, and the average value was $-9.66 \%$, with a large negative bias. The $\delta^{13} \mathrm{C}$ values of microcrystalline dolostone were between $1.38 \%$ and $-1.96 \%$, with an average value of $-0.66 \%$, and the $\delta^{18} \mathrm{O}$ values were between $-7.01 \%$ and $-8.72 \%$, and the average value was $-7.84 \%$. The $\delta^{13} \mathrm{C}$ values of the very fine crystalline dolostone were between $-0.06 \%$ and $-0.72 \%$, with an average value of $-0.3 \%$. The $\delta^{18} \mathrm{O}$ values of the very fine crystalline dolostone were between $-6.75 \%$ and $-8.93 \%$, and the average value was $-7.65 \%$. The $\delta^{13} \mathrm{C}$ and $\delta^{18} \mathrm{O}$ characteristics of different lithologies are shown in Figure 4.

Table 3. Isotope compositions of the $\mathrm{M}_{5}{ }^{5}$ from the Daniudi Gas Field in the Ordos Basin.

\begin{tabular}{|c|c|c|c|c|c|c|}
\hline $\begin{array}{l}\text { Sample } \\
\text { Number }\end{array}$ & Well & Depth (m) & Lithology & $\delta^{13} C_{\text {V-PDB }} \%$ & $\delta^{18} \mathrm{O}_{\text {V-PDB }} \%$ & ${ }^{87} \mathrm{Sr} /{ }^{86} \mathrm{Sr}$ \\
\hline S1 & D67 & 2892.28 & Microcrystalline limestone & -0.5 & -9.7 & 0.709082 \\
\hline S2 & D1-530 & 3097.42 & Very fine crystalline dolostone & -0.1 & -6.8 & 0.709711 \\
\hline S3 & D1-530 & 3101.42 & Microcrystalline dolostone & -0.2 & -8.1 & 0.709783 \\
\hline S4 & D1-530 & 3102.96 & Microcrystalline dolostone & 1.4 & -7.5 & 0.709637 \\
\hline S5 & D1-530 & 3102.99 & Very fine crystalline dolostone & -0.7 & -8.9 & 0.709067 \\
\hline S6 & D1-530 & 3105.53 & Microcrystalline dolostone & -2.0 & -8.7 & 0.709055 \\
\hline S7 & D1-530 & 3106.75 & Microcrystalline dolostone & -1.5 & -7.1 & 0.710430 \\
\hline S8 & D1-530 & 3108.28 & Microcrystalline dolostone & -0.3 & -7.5 & 0.709579 \\
\hline S9 & D1-530 & 3112.78 & Microcrystalline dolostone & -0.3 & -7.4 & 0.709766 \\
\hline S10 & D1-530 & 3115.62 & Microcrystalline dolostone & -0.1 & -7.5 & 0.710010 \\
\hline S11 & D48 & 3009.32 & Microcrystalline dolostone & -0.4 & -8.2 & 0.709228 \\
\hline S12 & D48 & 3013.00 & Microcrystalline dolostone & -1.8 & -8.4 & 0.709118 \\
\hline S13 & D48 & 3016.00 & Microcrystalline limestone & -0.5 & -8.3 & 0.709056 \\
\hline S14 & D48 & 3017.99 & Microcrystalline dolostone & -1.7 & -8.8 & 0.709367 \\
\hline $\mathrm{S} 15$ & D48 & 3020.38 & Microcrystalline limestone & -1.9 & -11.1 & 0.708797 \\
\hline S16 & D48 & 3026.35 & Microcrystalline limestone & -0.9 & -9.6 & 0.708902 \\
\hline S17 & PG27 & 2979.52 & Microcrystalline dolostone & -0.5 & -7.0 & 0.709561 \\
\hline S18 & PG27 & 2987.35 & Very fine crystalline dolostone & -0.1 & -7.3 & 0.709358 \\
\hline
\end{tabular}

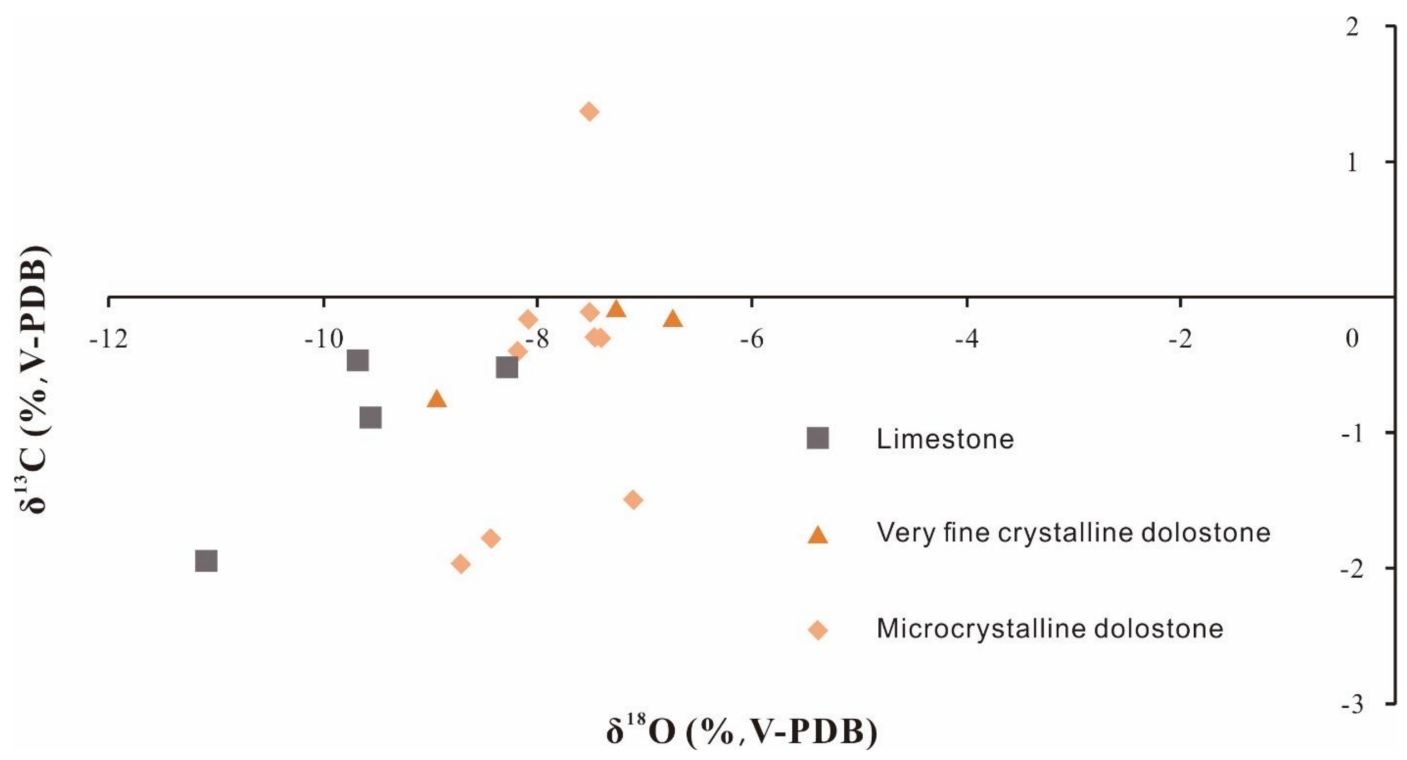

Figure 4. $\delta^{13} \mathrm{C}$ and $\delta^{18} \mathrm{O}$ of different lithologies in $\mathrm{M}_{5}{ }^{5}$ in Daniudi Gas Field, Ordos Basin. 
The strontium isotopes of the Ordovician seawater are distributed in the range $0.7087 \sim 0.7092$ [53-55]. The ${ }^{87} \mathrm{Sr} /{ }^{86} \mathrm{Sr}$ in the study area were generally higher than those of Ordovician seawater. The ${ }^{87} \mathrm{Sr} /{ }^{86} \mathrm{~S}$ of the limestone samples were relatively small, with an average of 0.708959 , which is in the range of the strontium isotopic composition of the Ordovician seawater. The ${ }^{87} \mathrm{Sr} /{ }^{86} \mathrm{~S}$ of microcrystalline dolostone and very fine crystalline dolostone samples were significantly higher than Ordovician seawater, with an average of 0.709594 and 0.709379 .

\subsection{Compositions of Major and Trace Elements}

The microcrystalline dolostone and very fine crystalline dolostone in the study area had a high content of $\mathrm{CaO}$; the average content of $\mathrm{CaO}$ in dolostone was $32.64 \%$ and $30.72 \%$, respectively (Table 4). These dolomites belonged to the Ca-rich dolomites. The very fine crystalline dolostone had a higher $\mathrm{Mg}$ content than that of the microcrystalline dolostone. The average $\mathrm{MgO}$ content of microcrystalline dolostone and very fine crystalline dolostone were $17.9 \%$ and $21.2 \%$, respectively. The content of Fe in the study area was significantly higher, with an average of $0.3 \%$, and the content of Mn was significantly lower, with an average of $0.008 \%$. The content of $\mathrm{Sr}$ ranged from $38.4 \times 10^{-6}$ to $116.7 \times 10^{-6}$, with an average of $76.46 \times 10^{-6}$.

Table 4. Relative content of the major elements and loss on ignition results of the samples.

\begin{tabular}{|c|c|c|c|c|c|c|c|c|c|c|c|c|c|}
\hline \multirow{2}{*}{$\begin{array}{l}\text { Sample } \\
\text { Number }\end{array}$} & \multirow{2}{*}{ Well } & \multirow{2}{*}{$\begin{array}{l}\text { Depth } \\
\text { (m) }\end{array}$} & \multirow{2}{*}{ Lithology } & \multicolumn{10}{|c|}{ Major Element (\%) } \\
\hline & & & & LOI & $\mathrm{K}_{2} \mathrm{O}$ & $\mathrm{Na}_{2} \mathrm{O}$ & $\mathrm{CaO}$ & $\mathrm{MgO}$ & $\mathrm{Al}_{2} \mathrm{O}_{3}$ & $\mathrm{TFe}_{2} \mathrm{O}_{3}$ & $\mathrm{MnO}$ & $\mathrm{TiO}_{2}$ & $\mathrm{P}_{2} \mathrm{O}_{5}$ \\
\hline S1 & D67 & 2892.28 & Microcrystalline limestone & 45.216 & 0.057 & 0.056 & 52.953 & 0.250 & 0.247 & 0.103 & 0.006 & 0.026 & 0.006 \\
\hline $\mathrm{S} 2$ & D1-530 & 3097.42 & Very fine crystalline dolostone & 44.329 & 0.051 & 0.062 & 31.721 & 22.120 & 0.186 & 0.213 & 0.007 & 0.024 & 0.006 \\
\hline S3 & D1-530 & 3101.42 & Microcrystalline dolostone & 45.058 & 0.080 & 0.060 & 34.362 & 19.180 & 0.264 & 0.266 & 0.008 & 0.029 & 0.008 \\
\hline S7 & D1-530 & 3106.75 & Microcrystalline dolostone & 47.907 & 1.023 & 0.079 & 26.277 & 19.220 & 3.351 & 0.991 & 0.019 & 0.217 & 0.077 \\
\hline S8 & D1-530 & 3108.28 & Microcrystalline dolostone & 45.119 & 0.101 & 0.063 & 32.538 & 21.020 & 0.332 & 0.298 & 0.007 & 0.026 & 0.013 \\
\hline S9 & D1-530 & 3112.78 & Microcrystalline dolostone & 46.902 & 0.079 & 0.060 & 31.863 & 19.760 & 0.286 & 0.337 & 0.008 & 0.026 & 0.013 \\
\hline S10 & D1-530 & 3115.62 & Microcrystalline dolostone & 48.023 & 0.287 & 0.064 & 30.239 & 19.370 & 1.051 & 0.390 & 0.008 & 0.034 & 0.022 \\
\hline S11 & D48 & 3009.32 & Microcrystalline dolostone & 47.981 & 0.082 & 0.053 & 37.744 & 13.060 & 0.293 & 0.234 & 0.008 & 0.026 & 0.011 \\
\hline S12 & D48 & 3013.00 & Microcrystalline dolostone & 50.201 & 0.061 & 0.053 & 38.352 & 10.530 & 0.211 & 0.224 & 0.008 & 0.022 & 0.007 \\
\hline S16 & D48 & 3026.35 & Microcrystalline limestone & 48.007 & 0.075 & 0.048 & 49.362 & 1.606 & 0.288 & 0.110 & 0.004 & 0.023 & 0.011 \\
\hline S17 & PG27 & 2979.52 & Microcrystalline dolostone & 48.150 & 0.080 & 0.054 & 29.811 & 20.730 & 0.302 & 0.199 & 0.006 & 0.024 & 0.010 \\
\hline S18 & PG27 & 2987.35 & Very fine crystalline dolostone & 48.839 & 0.056 & 0.054 & 29.726 & 20.330 & 0.221 & 0.260 & 0.008 & 0.019 & 0.009 \\
\hline
\end{tabular}

The rare earth element compositions of the studied samples are shown in Table 5. The data were standardized using Post-Archean Australian Shale (PAAS) [56,57], which eliminated the odd-even effect of rare earth elements and made the content and distribution of rare earth elements more intuitive (Table 5). Then, the enrichment and depletion of rare earth elements were reflected by numerical methods and graphical methods [58]. The results are shown in Figure 5. $\delta \mathrm{Ce}$ was calculated by the formula: $\delta \mathrm{Ce}=\mathrm{Ce} / \mathrm{Ce}^{*}=\mathrm{Ce}_{\mathrm{N}} /\left(0.5 \mathrm{La}_{\mathrm{N}}+0.5 \mathrm{Pr}_{\mathrm{N}}\right)$. $\delta \mathrm{Eu}$ was calculated by the formula: $\delta \mathrm{Eu}=\mathrm{Eu} / \mathrm{Eu}^{*}=\mathrm{Eu}_{\mathrm{N}} /\left(0.5 \mathrm{Sm}_{\mathrm{N}}+0.5 \mathrm{Gd}_{\mathrm{N}}\right)$. The calculation results show that the $\delta \mathrm{Ce}$ of the carbonate rocks in the study area was below 1 , with an average value of 0.9 , which was a relatively negative anomaly. $\delta \mathrm{Eu}$ was between 0.83 and 1.21 , with an average value of 1.04. Some samples had positive europium abnormity. The distribution patterns of rare earth elements were similar for the studied samples. 


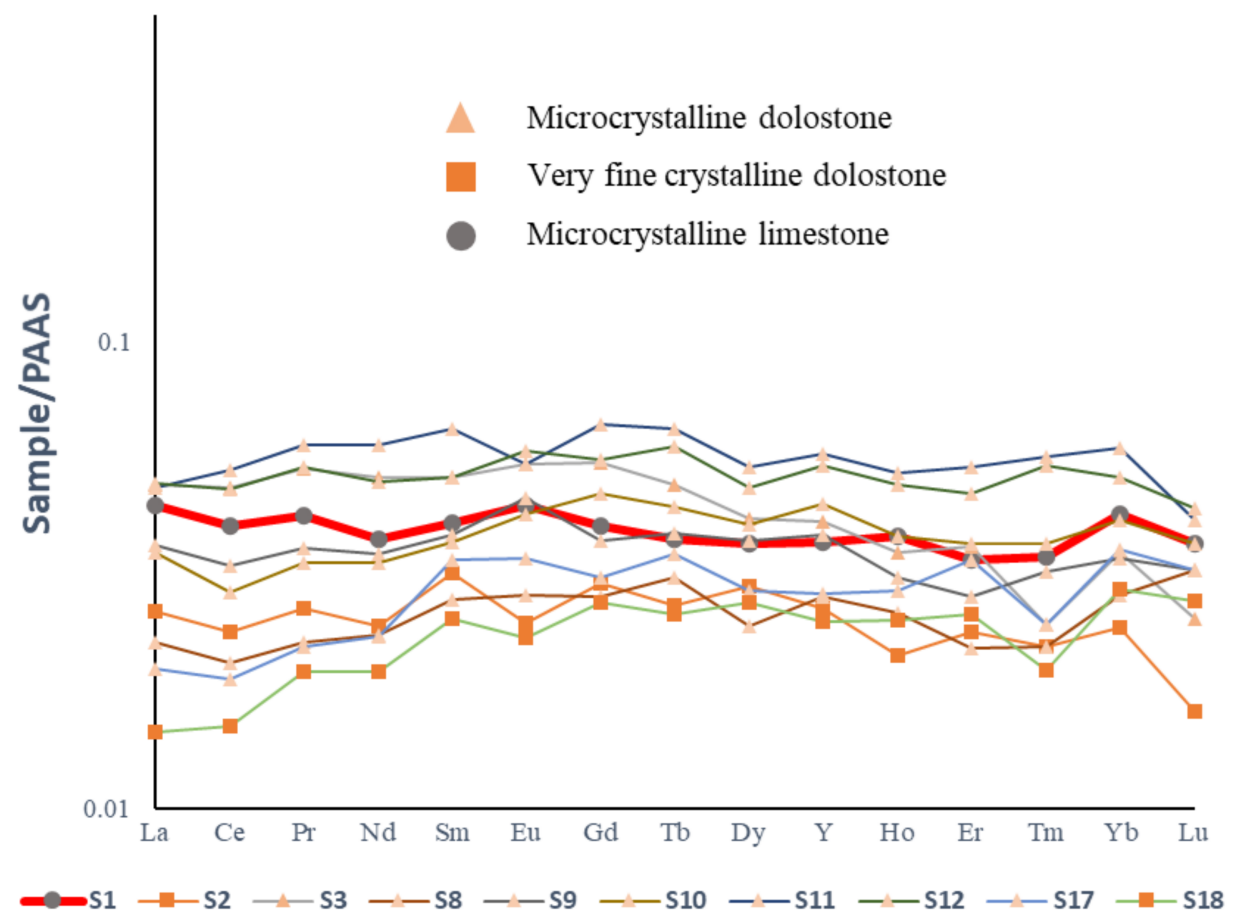

Figure 5. Distribution patterns of rare earth elements of carbonate in $\mathrm{M}_{5}{ }^{5}$ in the Daniudi Gas Field, Ordos Basin.

Table 5. Rare earth elements compositions of the $\mathrm{M}_{5}{ }^{5}$ from the Daniudi Gas Field in the Ordos Basin.

\begin{tabular}{|c|c|c|c|c|c|c|c|c|c|c|c|c|c|c|c|c|c|c|}
\hline \multirow{2}{*}{$\begin{array}{l}\text { Sample } \\
\text { Number }\end{array}$} & \multirow{2}{*}{ Well } & \multirow{2}{*}{$\begin{array}{l}\text { Depth } \\
\text { (m) }\end{array}$} & \multirow{2}{*}{ Lithology } & \multicolumn{15}{|c|}{ REE (ug/g) } \\
\hline & & & & La & $\mathrm{Ce}$ & $\operatorname{Pr}$ & Nd & $\mathrm{Sm}$ & Eu & Gd & $\mathrm{Tb}$ & Dy & $Y$ & Ho & Er & $\mathrm{Tm}$ & $\mathrm{Yb}$ & Lu \\
\hline S1 & D67 & 2892.28 & $\begin{array}{l}\text { Microcrystalline } \\
\text { limestone }\end{array}$ & 1.699 & 3.208 & 0.374 & 1.275 & 0.227 & 0.048 & 0.188 & 0.029 & 0.173 & 1.005 & 0.038 & 0.097 & 0.014 & 0.12 & 0.016 \\
\hline S2 & D1-530 & 3097.42 & $\begin{array}{l}\text { Very fine } \\
\text { crystalline } \\
\text { dolostone }\end{array}$ & 1.007 & 1.904 & 0.237 & 0.831 & 0.177 & 0.027 & 0.141 & 0.021 & 0.140 & 0.725 & 0.021 & 0.068 & 0.009 & 0.069 & 0.007 \\
\hline S3 & D1-530 & 3101.42 & $\begin{array}{l}\text { Microcrystalline } \\
\text { dolostone }\end{array}$ & 1.889 & 3.864 & 0.471 & 1.734 & 0.284 & 0.059 & 0.257 & 0.038 & 0.196 & 1.115 & 0.035 & 0.104 & 0.010 & 0.100 & 0.011 \\
\hline S8 & D1-530 & 3108.28 & $\begin{array}{l}\text { Microcrystalline } \\
\text { dolostone }\end{array}$ & 0.870 & 1.626 & 0.201 & 0.800 & 0.156 & 0.031 & 0.132 & 0.024 & 0.115 & 0.765 & 0.026 & 0.063 & 0.009 & 0.081 & 0.014 \\
\hline S9 & D1-530 & 3112.78 & $\begin{array}{l}\text { Microcrystalline } \\
\text { dolostone }\end{array}$ & 1.398 & 2.638 & 0.319 & 1.187 & 0.214 & 0.050 & 0.175 & 0.030 & 0.175 & 1.039 & 0.031 & 0.081 & 0.013 & 0.097 & 0.014 \\
\hline S10 & D1-530 & 3115.62 & $\begin{array}{l}\text { Microcrystalline } \\
\text { dolostone }\end{array}$ & 1.347 & 2.306 & 0.297 & 1.141 & 0.206 & 0.046 & 0.221 & 0.034 & 0.190 & 1.217 & 0.038 & 0.105 & 0.015 & 0.117 & 0.016 \\
\hline S11 & D48 & 3009.32 & $\begin{array}{l}\text { Microcrystalline } \\
\text { dolostone }\end{array}$ & 1.865 & 4.231 & 0.530 & 2.036 & 0.362 & 0.059 & 0.309 & 0.050 & 0.252 & 1.554 & 0.052 & 0.153 & 0.023 & 0.167 & 0.018 \\
\hline S12 & D48 & 3013.00 & $\begin{array}{l}\text { Microcrystalline } \\
\text { dolostone }\end{array}$ & 1.905 & 3.852 & 0.474 & 1.696 & 0.285 & 0.063 & 0.261 & 0.046 & 0.228 & 1.460 & 0.049 & 0.135 & 0.022 & 0.144 & 0.019 \\
\hline S17 & PG27 & 2979.52 & $\begin{array}{l}\text { Microcrystalline } \\
\text { dolostone }\end{array}$ & 0.761 & 1.505 & 0.196 & 0.794 & 0.189 & 0.037 & 0.146 & 0.027 & 0.137 & 0.780 & 0.029 & 0.097 & 0.010 & 0.101 & 0.014 \\
\hline S18 & PG27 & 2987.35 & $\begin{array}{l}\text { Very fine } \\
\text { crystalline } \\
\text { dolostone }\end{array}$ & 0.555 & 1.197 & 0.173 & 0.663 & 0.141 & 0.025 & 0.129 & 0.020 & 0.129 & 0.679 & 0.025 & 0.074 & 0.008 & 0.083 & 0.012 \\
\hline
\end{tabular}




\section{Discussion}

\subsection{Dolomitization Fluid}

Isotopic characteristics can reflect the properties of the dolomitization fluid. The isotope characteristics of limestone were similar to those of Ordovician seawater. Compared with the Ordovician seawater, the isotope characteristics of the dolostone had a certain deviation. The $\delta^{13} \mathrm{C}$ value range of the dolostone was similar to that of seawater, but the $\delta^{18} \mathrm{O}$ and ${ }^{87} \mathrm{Sr} /{ }^{86} \mathrm{Sr}$ were higher than that of the Ordovician seawater. According to the ancient salinity formula derived by Keith and Weber [59,60]:

$$
Z=2.048\left(\delta^{13} \mathrm{C}+50\right)+0.498\left(\delta^{18} \mathrm{O}+50\right)
$$

In the formula, $\delta^{13} \mathrm{C}$ is the carbon isotope measurement result, and $\delta^{18} \mathrm{O}$ is the oxygen isotope measurement result.

The calculation results showed that the $Z$-values of carbonate rocks were all greater than 120 . The average $Z$ of limestone was 120.5 , and the average $Z$ of the dolostone was 122.2 (Table 6), indicating that the salinity of the dolomitization fluid was slightly higher than that of seawater. The calculation of salinity showed that the dolomite in the study area was not of freshwater origin. This medium-salinity brine is likely from seawater, the salinity of which would be increased after being subjected to evaporation.

The ${ }^{87} \mathrm{Sr} /{ }^{86} \mathrm{Sr}$ of limestone in the study area was similar to that of seawater, but the ${ }^{87} \mathrm{Sr} /{ }^{86} \mathrm{Sr}$ of dolostone was higher than that of Ordovician seawater. This phenomenon could be attributed to the fractionation of strontium isotopes caused by atmospheric freshwater when the formation of dolostone happened in the evaporation environment of the regression period. The modification of atmospheric freshwater during the supergene period in the study area might also have increased the Sr isotope [16], because the dolomite observed under CL was dark red and the determination of the major element also showed that the content of $\mathrm{Mn}^{2+}$ was low. It could be concluded that the dolomitization fluid was a sea-sourced fluid, and the environment where dolomitization occurred was the epicontinental sea during the regression period and the evaporative environment formed by the emergence of highlands due to the drop in sea level.

When sediment is in the oxidized seawater, the easily soluble $\mathrm{Ce}^{3+}$ will be transformed into thermodynamically stable and weaker migration ability $\mathrm{Ce}^{4+}$, which will preferentially adhere to the surface of the sediment particles and precipitate, causing the $\mathrm{Ce}$ in the sediment to show a positive anomaly. Therefore, the negative anomaly of Ce usually indicates the environment of oxidized seawater [61-63]. The positive Eu anomaly of chemical sedimentary rocks was related to the high temperature $\left(>200{ }^{\circ} \mathrm{C}\right)$ reductive hydrothermal fluids $[61,64-68]$. According to the calculation results of $\delta \mathrm{Eu}$ and $\delta \mathrm{Ce}$, the water in the study area was oxidized seawater and was less affected by hydrothermal fluid in the late diagenesis of carbonate rocks. 
Table 6. Salinity and Calculation results of REE.

\begin{tabular}{ccccccc}
\hline Sample Number & Well & Depth $(\mathbf{m})$ & Lithology & Salinity (Z) & $\delta$ Ce & $\delta$ Eu \\
\hline S1 & D67 & 2892.28 & Microcrystalline limestone & 121.54 & 0.93 & 1.09 \\
S2 & D1-530 & 3097.42 & Very fine crystalline dolostone & 123.67 & 0.90 & 0.81 \\
S3 & D1-530 & 3101.42 & Microcrystalline dolostone & 122.94 & 0.94 & 1.03 \\
S4 & D1-530 & 3102.96 & Microcrystalline dolostone & 126.39 & $/$ & $/$ \\
S5 & D1-530 & 3102.99 & Very fine crystalline dolostone & 121.38 & $/$ & $/$ \\
S6 & D1-530 & 3105.53 & Microcrystalline dolostone & 118.9 & $/$ \\
S7 & D1-530 & 3106.75 & Microcrystalline dolostone & 120.73 & $/$ & $/$ \\
S8 & D1-530 & 3108.28 & Microcrystalline dolostone & 123.01 & 0.90 & 1.02 \\
S9 & D1-530 & 3112.78 & Microcrystalline dolostone & 123.00 & 0.91 & 1.22 \\
S10 & D1-530 & 3115.62 & Microcrystalline dolostone & 123.34 & 0.84 & 1.01 \\
S11 & D48 & 3009.32 & Microcrystalline dolostone & 122.45 & 0.98 & 0.83 \\
S12 & D48 & 3013.00 & Microcrystalline dolostone & 119.48 & 0.94 & 1.09 \\
S13 & D48 & 3016.00 & Microcrystalline limestone & 122.13 & $/$ & $/$ \\
S14 & D48 & 3017.99 & Microcrystalline dolostone & 119.43 & $/$ & $/$ \\
S15 & D48 & 3020.38 & Microcrystalline limestone & 117.80 & $/$ & $/$ \\
S16 & D48 & 3026.35 & Microcrystalline limestone & 120.73 & $/$ & $/$ \\
S17 & PG27 & 2979.52 & Microcrystalline dolostone & 122.72 & 0.90 & 1.05 \\
S18 & PG27 & 2987.35 & Very fine crystalline dolostone & 123.56 & 0.88 & 0.87 \\
\hline
\end{tabular}

\subsection{Origin of Dolomite}

The $\mathrm{MgO} / \mathrm{CaO}$ in dolostone can also reflect the sedimentary origin or metasomatic origin of dolostone. The content of $\mathrm{MgO}$ and $\mathrm{CaO}$ in dolostone formed by sedimentary origin is usually positively correlated, and the content of $\mathrm{MgO}$ and $\mathrm{CaO}$ in dolostone formed by replacement or recrystallization is usually negatively correlated. As shown in Figure 6, there was a negative correlation between $\mathrm{MgO}$ and Cao in micritic dolomite, silty dolomite, and limestone with a small amount of dolomite in the study area; thus, it was considered that dolomite was metasomatic. In addition, the $\mathrm{MgO} / \mathrm{CaO}$ ratio of very fine crystalline dolostone was higher, and the $\mathrm{MgO} / \mathrm{CaO}$ ratio of microcrystalline limestone was slightly lower. $\mathrm{MgO} / \mathrm{CaO}$ was the main controlling factor for the degree of dolomitization. Generally, the higher the $\mathrm{MgO} / \mathrm{CaO}$ ratio, the more likely dolomitization occurs.

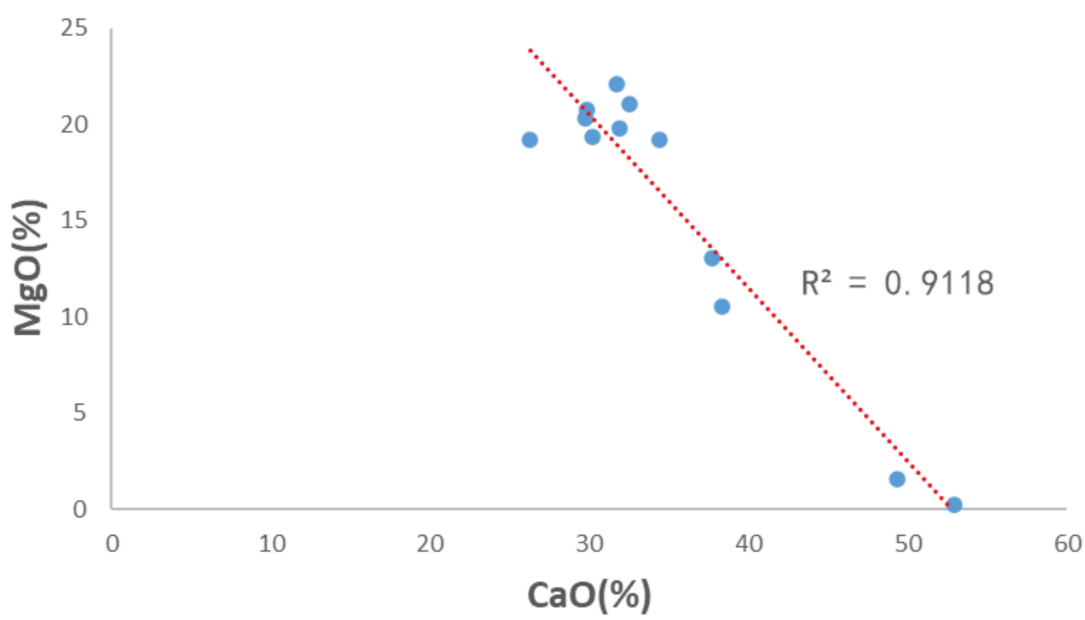

Figure 6. $\mathrm{MgO} / \mathrm{CaO}$ cross plot of carbonate in $\mathrm{M}_{5}{ }^{5}$ in the Daniudi Gas Field, Ordos Basin.

The dolomite in the study area was Ca-rich non-stoichiometric dolomite, and the crystal size was quite small, generally less than $0.1 \mathrm{~mm}$. The degree of order in dolomite were mostly between 0.6 and 0.9 , and the values showed a trend of high and low fluctuations in the longitudinal direction, without obvious regularity. According to the characteristics of dolomite and fluid properties, it was judged that this kind of dolomite was the cause of 
penecontemporaneous brine seepage-reflux mechanism. The lithology changed frequently in areas with higher altitude in the study area, the minimum thickness of the limestonedolostone cycle was approximately $3 \mathrm{~m}$, and it was often accompanied by shallow water signs such as laminae and wormholes (Figure 3h,i). All these phenomena showed that the development of dolostone in the study area was controlled by the change in sea level. Therefore, it could be concluded that the dolomitized brine originated from the evaporation environment created by frequent changes in sea level during the penecontemporaneous period. When the sea level dropped, the surface limestone was exposed, and the water retained in the exposed surface was evaporated, which caused the salinity to rise, and then dolomitization occurred in some areas.

\subsection{Dolomitization Mechanism}

The dolomitization in the study area was the cause of seepage-reflux controlled by sedimentary paleogeomorphology under frequent sea level changes. During the regression period, the surface of the higher altitude area that was submerged in the previous period would be exposed to form an evaporation environment. The water trapped in the highlands and low-lying areas of the platform would be evaporative and, thus, caused the increase in salinity and $\mathrm{Mg} / \mathrm{Ca}$. At this time, under the effect of the potential energy difference and the difference in ion concentration, the brine with medium salinity would infiltrate and metasomatize the limestone deposited in the early stage and form dolostone [69-71]. The higher elevation of the western highlands made it easier for brine to seep downwards. Moreover, because areas with higher altitudes took longer to expose the surface during regression, the brine was subject to a longer period of evaporation so that the salinity and $\mathrm{Mg} / \mathrm{Ca}$ were higher. Therefore, the thickness of dolostone in the western highlands was larger, and it was easier to form very fine crystalline dolostone with larger pores. The strata extending to the east and north were less affected by sea level, resulting in the thin thickness of dolostone. The depression area had been below sea level for a long time, it belongs to the relatively deeper water deposition at most times. There was no evaporation environment for the development of dolostone, only microcrystalline limestone developed. As the $\mathrm{M}_{5}{ }^{5}$ was in a period of transgression and regression interaction, frequent sea level fluctuations caused the change in sedimentary environment in the western highlands between the evaporative tidal flat environment and the relatively deeper water environment. This change made the formation of dolomitization fluids easier. The highlands caused by brine seepage after the sea receded were firstly dolomitized (Figure 7a). As the sea level dropped, dolomites continued to form on the exposed surface, while the brine on the high ground in the early stage was further evaporated to form gypsum. In the subsequent transgression period, as the sea level rise, the highland evolved into a tidal flat environment. The strata affected by the dolomitization in the early stage will be infiltrated by brine again, it was easier to form very fine crystalline dolostone during the process of being modified by dolomitizing fluids many times (Figure $7 \mathrm{~b}$ ). After the sea level continued to rise until the highlands were submerged, the study area became a relatively deeper water environment, at which time microcrystalline limestone was mainly deposited (Figure 7c). When the surface was exposed during the next regression period, this dolomitization pattern occurred again. After that, the periodic changes in sea level led to the development of multiple periods of limestone-dolomite cycles in the western highlands of the study area. 


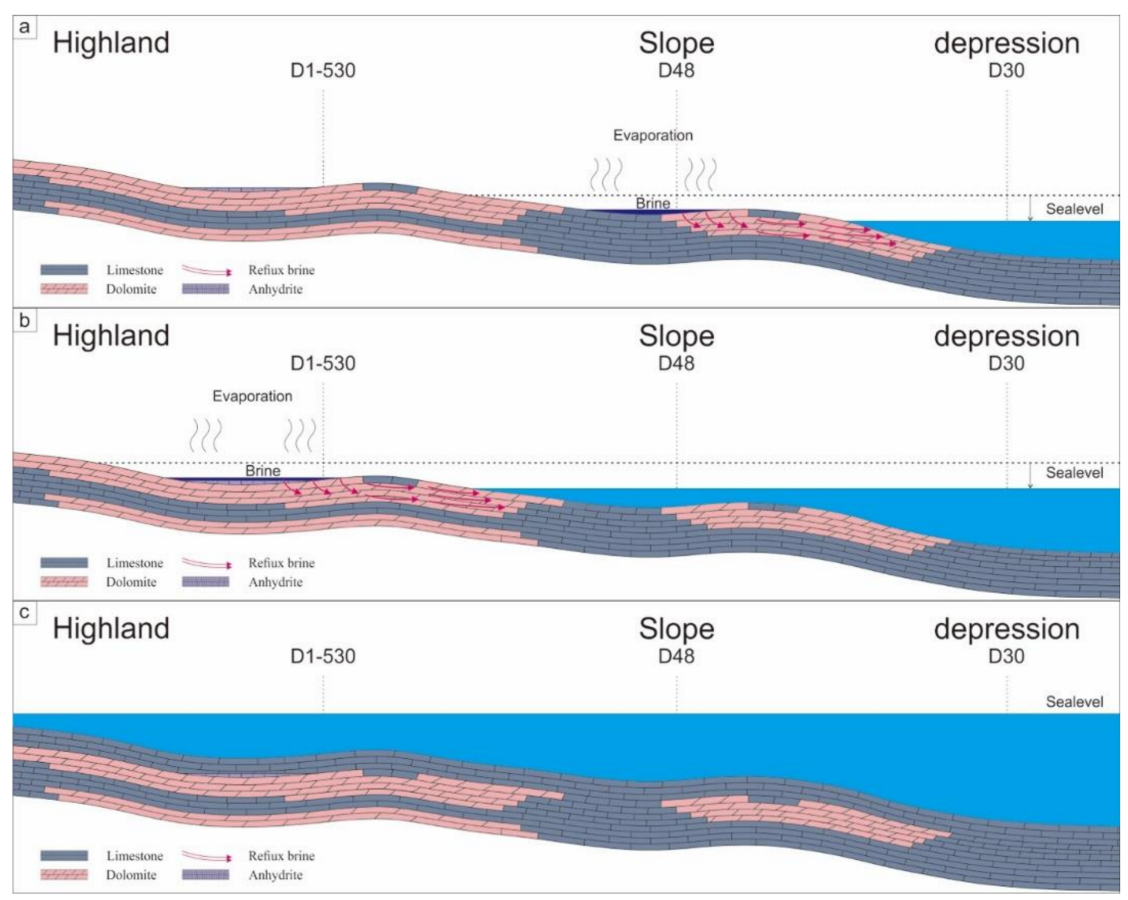

Figure 7. Dolomitization model in $\mathrm{M}_{5}{ }^{5}$ in Daniudi Gas Field, Ordos Basin. (a) Slope dolomitization during regression period; (b) Highland dolomitization during the transgression period; (c) Limestone was deposited during the highest sea level period.

The dolomitization in this model was not uniform. The $\mathrm{Mg}^{2+}$ content of the evaporated $\mathrm{Mg}^{2+}$-rich brine would gradually decrease as the fluid moved during the process of migration, and with the reaction with the limestone, dolomitization would become increasingly weaker, so the limestone layer in contact with the bottom of the brine would undergo strong dolomitization, which also led to the development of thinner dolostone in relatively low-lying areas. However, this kind of dolostone might only develop when the sea level was low in the early stage $\mathrm{M}_{5}{ }^{5}$, and its thickness and distribution range were very small so that it was impossible to form a reservoir. Overall, the formation of the dolostone in the study area required the evaporation of the environment and the difference in topography, which were all controlled by the characteristics of the paleogeomorphology. The limestone in the highlands was susceptible to multiple seepage-reflux of dolomitization fluid, and the dolomitization fluid on the highlands had a higher $\mathrm{Mg} / \mathrm{Ca}$ ratio, which was more beneficial to dolomitization. Very fine crystalline dolostone and large-scale dolostone reservoirs were more easily formed on the highlands.

\subsection{The Distribution of Dolostone and Its Relationship with Paleogeomorphology}

Because the $\mathrm{M}_{4}$ has a stable thickness distribution in the study area, assuming that the top of the fourth member of Majiagou Formation is horizontal, the paleogeomorphology conditions can be simulated by calculating the cumulative thickness of $\mathrm{M}_{5}{ }^{6}-\mathrm{M}_{5}{ }^{10}$. According to the statistics of the cumulative thickness of dolostone in Figure 8 and the comparison of paleogeomorphic characteristics, it was found that paleogeomorphic conditions had a greater influence on the planar distribution of dolostone. The higher the geomorphology in the same area, the greater the cumulative thickness of dolostone. Since the dolostone in the study area was the cause of frequent sea-level oscillations, the higher the altitude, the greater the impact of sea level, the more limestone-dolostone cycles were developed, thus the greater the cumulative thickness of the dolostone. In addition, the locally developed platform might be exposed to the surface during the period of sea-level decline. At this time, dolomitization would occur on the exposed surface, but the formation of dolostone reservoirs was small in scale and spatially discontinuous. However, the depression area 
was submerged by seawater most of the time due to the low sea-level and could not provide the conditions for dolomitization. Therefore, there was very little dolostone development, and most areas were dominated by microcrystalline limestone. The well D1-530 in the study area was one of the highest wells in the study area. It was greatly affected by sea-level changes. It had developed a five-stage limestone-dolostone cycle, and there were three layers of very fine crystalline dolostone in the reservoir (Figure 8b). The thicknesses of the dolostone in well PG27 and well D48 on the slope were significantly reduced. The development of four stages of lithological cycles in well D48 also showed that the location of the well was relatively weakened by sea-level changes (Figure 8b). Wells D30 and D37 were in the depression area and were submerged by sea water for a long period of time. There was basically no dolomitization in the depression area, and there was also no condition for the formation of dolostone reservoirs (Figure 8b). The flow direction of the dolomitization fluid must be from top to bottom, from the brine to the ocean. Therefore, the best conditions for the development of dolostone should be the high ground. Except for the altitude factors, the dolomitization of the area was also related to slope. In areas with steep slopes, the area exposed to the surface during the period of small changes in sea level was small, which was not conducive to dolomitization under this model, thus a gentle slope is conducive to the formation of dolomite under the same conditions. This could explain the development of thick dolostone developed in wells PG27 and D48. In summary, the distribution of dolomite reservoirs was predicted based on the characteristics of paleogeomorphology. According to the restoration of paleogeomorphology, it was shown that the topography of the study area had small undulations and gentle slopes. The shallower water depth and gentle slope in this sedimentary environment resulted in a larger scale of surface exposure during the regression period. When the altitude reached a certain limit, dolostone developed on a large scale. However, this dolostone reservoir had a larger lateral extension range, which was easier to continuously form layers and provided favorable conditions for oil and gas enrichment.

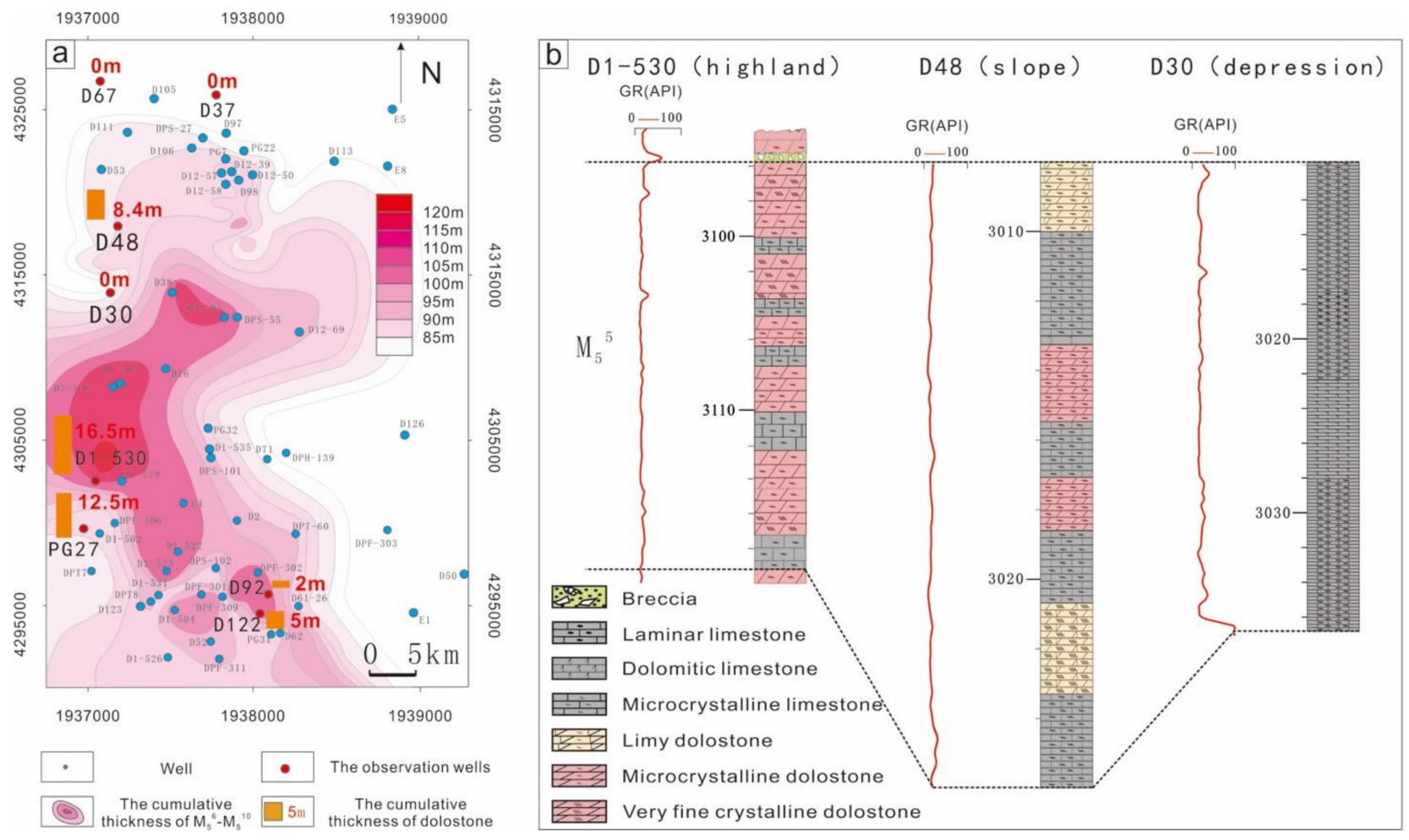

Figure 8. The relationship between the thickness of dolostone and paleogeomorphology in $\mathrm{M}_{5}{ }^{5}$ in Daniudi Gas Field, Ordos Basin: (a) dolostone thickness distribution and paleogeomorphology characteristics; (b) dolomite thickness and lithological cycles characteristics under different paleogeomorphology in the $\mathrm{M}_{5}{ }^{5}$. 
According to the above study on the properties of dolomitization fluid, it could be concluded that the formation of dolostone in the study area had nothing to do with the karst water in the supergene period. The karst water in the supergene period only formed calcite cement (Figure 3). The reason why the distribution of dolomite was consistent with the characteristics of paleokarst landform was because the paleokarst landform inherits the characteristics of the sedimentary paleogeomorphology. Sedimentary paleogeomorphology had a controlling effect on dolomitization, and it was easier to expose and form continuous thick layers of dolomite in areas with higher altitude and gentle slopes.

\section{Conclusions}

(a) The 5th sub-member in the 5 Member of the Ordovician Majiagou Formation in the Daniudi Gas Field were mainly composed of microcrystalline limestone, microcrystalline dolostone, and very fine crystalline dolostone. The characteristics of microscopic and core observations showed that dolomitization occurred in the shallow-water facies. Dolomite was dark red under cathodoluminescence, and the degree of order in dolomite was between 0.63 and 0.91 . The dolomitization fluid came from seawater which experienced a certain degree of evaporation. The formation of dolostone was due to the seepage-reflux of brine in the penecontemporaneous period.

(b) The distribution of dolostone in the $\mathrm{M}_{5}{ }^{5}$ of the Daniudi Gas Field was controlled by sedimentary paleogeomorphology. The strong correlation between the distribution of dolostone and paleokarst landform was attributed to the inheritance of paleokarst landform to sedimentary paleogeomorphology. During periods of frequent sea-level changes, higher terrain areas were more vulnerable to sea-level changes. Therefore, it was easier to develop multi-period cycles of limestone and dolostone, resulting in a larger cumulative thickness of dolostone. Highlands were subject to evaporation for a longer period and, thus, more easily formed very fine crystalline dolostone.

(c) Under the gentle slope of the epicontinental sea, dolostone was more likely to develop extensively on a large-scale exposed surface during the regressing period. The change in sea level had a greater impact on the tidal flat environment under such geo-morphic conditions. Moreover, the distribution of dolostone had good continuity in plane. The unoriented flow and uneven effect of the seepage-reflux dolomitization fluid caused the difference in the distribution of dolostone. Overall, limestone under the evaporation environment on the highlands was widely dolomitized, and the higher terrain and slower slope contributed to the development of large-scale dolostone reservoirs.

Author Contributions: Investigation and writing, Y.L.; verification, W.X.; methodology, M.F.; resources, H.D.; project administration D.W.; data curation, J.H.; validation, H.G. and P.C. All authors have read and agreed to the published version of the manuscript.

Funding: This research was funded by Open Fund (PLC2020023) of State Key Laboratory of Oil and Gas Reservoir Geology and Exploitation (Chengdu University of Technology) awarded to W.X. The APC was funded by M.F.

Data Availability Statement: The data presented in this study are available on request from the corresponding author.

Acknowledgments: This research was supported by Sinopec North China Oil \& Gas Branch. Thank you for the data provided by Sinopec North China Oil and Gas Branch, and thank two reviewers for their vital comments.

Conflicts of Interest: The authors declare no conflict of interest.

\section{References}

1. Allan, J.R.; Wiggins, W.D. Dolomite Reservoirs: Geochemical Techniques for Evaluating Origin and Distribution; American Association of Petroleum Geologists: Tulsa, OK, USA, 1993; Volume 36. 
2. Guo, C.; Chen, D.; Qing, H.; Zhou, X.; Ding, Y. Early dolomitization and recrystallization of the Lower-Middle Ordovician carbonates in western Tarim Basin (NW China). Mar. Pet. Geol. 2020, 111, 332-349. [CrossRef]

3. Liu, D.; Cai, C.; Hu, Y.; Peng, Y.; Jiang, L. Multistage dolomitization and formation of ultra-deep Lower Cambrian Longwangmiao Formation reservoir in central Sichuan Basin, China. Mar. Pet. Geol. 2021, 123, 104752. [CrossRef]

4. Zengler, D.H.; Dunham, J.; Ethington, R.L. Concepts and Models of Dolomitization; Society of Economic Paleontologists and Mineralogi: London, UK, 1980; pp. 51-67.

5. Gunatilaka, A. Dolomite formation in coastal Al-Khiran, Kuwait Arabian Gulf-A re-examination of the sabkha model. Sediment. Geol. 1991, 72, 35-53. [CrossRef]

6. Shen, A.; Zheng, J.; Chen, Y.; Ni, X.; Huang, L. Characteristics, origin and distribution of dolomite reservoirs in Lower-Middle Cambrian, Tarim Basin, NW China. Pet. Explor. Dev. 2016, 43, 375-385. [CrossRef]

7. Kaufman, J. Numerical models of fluid flow in carbonate platforms; implications for dolomitization. J. Sediment. Res. 1994, 64, 128-139.

8. Melim, L.; Scholle, P. Dolomitization of the Capitan Formation forereef facies (Permian, west Texas and New Mexico): Seepage reflux revisited. Sedimentology 2002, 49, 1207-1227. [CrossRef]

9. Lu, P.; Cantrell, D. Reactive transport modelling of reflux dolomitization in the Arab-D Reservoir, Ghawar Field, Saudi Arabia. Sedimentology 2016, 63, 865-892. [CrossRef]

10. Aharon, P.; Socki, R.A.; Chan, L. Dolomitization of atolls by sea water convection flow: Test of a hypothesis at Niue, South Pacific. J. Geol. 1987, 95, 187-203. [CrossRef]

11. Ren, M.; Jones, B. Genesis of island dolostones. Sedimentology 2018, 65, 2003-2033. [CrossRef]

12. Lu, F.; Meyers, W. Massive dolomitization of a Late Miocene carbonate platform: A case of mixed evaporative brines with meteoric water, Nijar, Spain. Sedimentology 2008, 45, 263-277. [CrossRef]

13. Nader, F.; Rudy, S.; Ellam, R. Reflux stratabound dolostone and hydrothermal volcanism-associated dolostone: A two-state dolomitization model (Jurassic, Lebanon). Sedimentology 2004, 51, 339-360. [CrossRef]

14. Conliffe, J.; Azmy, K.; Gleeson, S.A.; Lavoie, D. Fluids associated with hydrothermal dolomitization in St. George Group, western Newfoundland, Canada. Geofluids 2010, 10, 422-437. [CrossRef]

15. Bahnan, A.E.; Carpentier, C.; Pironon, J.; Ford, M.; Ducoux, M.; Barré, G.; Mangenot, X.; Gaucher, E.C. Impact of geodynamics on fluid circulation and diagenesis of carbonate reservoirs in a foreland basin: Example of the Upper Lacq reservoir (Aquitaine basin, SW France). Mar. Pet. Geol. 2020, 111, 676-694. [CrossRef]

16. Duggan, J.P.; Mountjoy, E.W.; Stasiuk, L.D. Fault-controlled dolomitization at Swan Hills Simonette oil field (Devonian), deep basin west-central Alberta, Canada. Sedimentology 2001, 48, 301-323. [CrossRef]

17. Hollis, C.; Bastesen, E.; Boyce, A.; Corlett, H.; Gawthorpe, R.; Hirani, J.; Rotevatn, A.; Whitaker, F. Fault-controlled dolomitization in a rift basin. Geology 2017, 45, 219-222. [CrossRef]

18. Koeshidayatullah, A.; Corlett, H.; Stacey, J.; Swart, P.K.; Boyce, A.; Robertson, H.; Whitaker, F.; Hollis, C. Evaluating new fault-controlled hydrothermal dolomitization models: Insights from the Cambrian Dolomite, Western Canadian Sedimentary Basin. Sedimentology 2020, 67, 2945-2973. [CrossRef]

19. Kupecz, J.; Kerans, C.; Land, L.; Lee, Y.; Friedman, G. Deep-burial dolomitization in the Ordovician Ellenburger Group carbonates, West Texas and southern New Mexico; discussion and reply. J. Sediment. Res. 1988, 58, 908-913. [CrossRef]

20. Jiang, L.; Cai, C.; Worden, R.; Crowley, S.; Jia, L.; Zhang, K.; Duncan, I. Multiphase dolomitization of deeply buried Cambrian petroleum reservoirs, Tarim Basin, north-west China. Sedimentology 2016, 63, 2130-2157. [CrossRef]

21. Shi, B.; Liu, Y.; Wu, C.; Huang, Z.; Ren, J. Geological conditions for hydrocarbon accumulation in middle reservoir-source rock combination of the Ordovician Majiagou Formation on the east side of the paleo-uplift in Ordos Basin. Oil Gas Geol. 2013, 34, 610-618.

22. Li, W.; Tu, J.; Zhang, J.; Zhang, B. Accumulation and potential analysis of self-sourced natural gas in the Ordovician Majiagou Formation of Ordos Basin, NW China. Pet. Explor. Dev. 2017, 44, 552-562. [CrossRef]

23. Tu, J.; Dong, Y.; Zhang, B.; Nan, H.; Li, C.; Wang, X.; Fei, X.; Zhou, W. Discovery of effective scale source rocks of the Ordovician Majiagou Fm in the Ordos Basin and its geological significance. Nat. Gas Ind. B 2016, 36, 15-24. [CrossRef]

24. Tang, M. Study on the Formation Characteristics of the Weathere Ma 5 Layer of Ordovician System in Daniudi Gas Field. Master's Thesis, Southwest Petroleum University, Chengdu, China, 4 December 2017.

25. Luo, X. The Research on Dolomite Genesis and the Sedimentary Evolution of Ordovician Majiagou Formation Ma 5 Submember in Daniudi Area. Master's Thesis, Chengdu University of Technology, Chengdu, China, 13 June 2013.

26. Bai, X. Origin of Dolomite and Dolomite Reservoir Development in Middle Ordovician M55 Sub-Member Platform Carbonates in the Daniudi Area, Northern Ordos Basin, Western China. Ph.D. Thesis, Southwest Petroleum University, Chengdu, China, 7 June 2016.

27. Luo, Q.; Liu, B.; Jiang, W.; Yu, S.; Wang, Y.; Wei, L.; Cai, Z. Diagenesis and pore evolution of dolomite reservoir in the 5th member of the Ordovician Majiagou Formation, central Ordos Basin. Oil Gas Geol. 2020, 41, 102-115.

28. Ren, J.; Yang, W.; Ding, X.; Zhao, W.; Huang, L.; Wei, L. Discussion on characteristics and origin of Majiagou Formation dolomite reservoir in Ordos Basin, China. J. Chengdu Univ. Technol. Sci. Technol. Ed. 2016, 43, 274-281.

29. Li, F.; Du, L.; Zhao, J.; Li, Y.; Xiang, F.; Li, F. Dolomite genesis in Member Ma5 5 of Majiagou Formation, Sudong area, Ordos Basin. Acta Pet. Sin. 2016, 37, 328-338. 
30. Yu, C.; Cui, J. Geochemical Characteristics and Genesis of Dolomite in Majiagou Ma55 Submember of the Northeast Yishan Slope, Ordos Basin. Earth Sci. 2019, 44, 2761-2774.

31. Zuo, Z.; Xiong, Y.; He, W.; Yang, B.; Ren, L.; Wen, H.; Liu, G.; Liu, L.; Tan, X. Diagenesis and Porosity Evolution of the Subsalt Member 5 of Majiagou Formation Reservoir in the Central Ordos Basin. Bull. Geol. Sci. Technol. 2019, 38, 155-164.

32. He, M.; Huang, W.; Jiu, B. Origin and evolution of favorable reservoir of gypsum dolomite in Ordos basin. China Earth Sci. Front. 2021, in press. [CrossRef]

33. Tang, M. Dolomite reservoir characteristics and distribution regularity of Ma5-5 reservoirs in Daniudi gasfield. Pet. Geol. Eng. 2017, 31, 29-32/131-132.

34. Zheng, R.; Dang, R.; Zheng, C.; Wen, H.; Zhou, G.; Xu, F. Diagenetic system of carbonate reservoir in Huanglong Formation from East Sichuan to North Chongqing area. Acta Pet. Sin. 2010, 31, 237-245.

35. Hu, Z.; Zheng, R.; Wen, H.; Cai, J.; Chen, S.; Hu, J.; Li, G. Dolostone genesis of Huanglong Formation of Carboniferous in Linshui of Eastern Sichuan-northern Chongqing area. Acta Petrol. Sin. 2008, 24, 1369-1378.

36. Liu, S.; Hu, M.; Hu, Z.; Dai, Y. Dolomite genesis of Carboniferous Huanglong Formation in eastern Sichuan Basin. Lithol. Reserv. 2015, 27, 40-46.

37. Su, Z.; Chen, H.; Ou, Y.Z.; Jin, X. Sequence-based lithofacies and paleogeography of Majiagou Formation in Ordos Basin. Geol. China 2012, 39, 623-633.

38. Huang, Z.; Wu, C.; Ma, Z.; Ren, J.; Bao, H. Sedimentary Sequence of Ordovician Majiagou Formation in Central and Eastern Part of Ordos Basin and Its Control over Reservoir Development. China Pet. Explor. 2015, 20, $20-29$.

39. Wang, Q.; Zhang, Y.; Yang, Y.; Yang, L.; Li, J. Sequence stratigraphic and lithofacies distributions of Majiagou Formation in Ordos Basin. J. Northwest Univ. Nat. Sci. Ed. 2015, 20, 20-29.

40. Wang, L.; Mei, C.; Li, Y.; Zhao, J. Sequence stratigraphic features and their control over hydrocarbon accumulation of Ordovician Majiagou formation in the Ordos Basin. J. Northeast. Pet. Univ. 2018, 42, 26-36/112/124-125.

41. Jiang, S.; Jiang, Y.; Huang, W.; Xing, E.; Gui, B.; Peng, Y.; Zhao, H.; Shang, W. Geochemical characteristics of Ordovician strontium isotope in the Ordos Basin. Acta Geol. Sin. 2019, 93, 2889-2903.

42. Lei, T.; Deng, H.; Wu, D.; Fu, M.; Tang, M.; Cui, L.; Ding, X.; Xia, Y.; Xie, X. Depositional model of the lower-middle Ordovician Majiagou Formation in Daniudi Gas Field, Ordos Basin. J. Palaeogeogr. Chin. Ed. 2020, 22, 523-538.

43. Wu, W.; Wang, Y.; Zhao, J.; Yang, T.; Li, J.; Huang, Z. The rule of nature gas accumulation of the mid-assemblage of Ordovician Majiagou Formation in the central Ordos Basin. Nat. Gas Geosci. 2019, 30, 828-839.

44. Lei, H.; Huang, W.; Yi, S.; Wang, Y. Dissolution characteristics of deep-buried dolostone in the Member 5 of Ordovician Majiagou Formation in southern Ordos Basin. J. Palaeogeogr. Chin. Ed. 2020, 22, 1041-1052.

45. Fu, S.; Zhang, C.; Chen, H.; Chen, A.; Zhao, J.; Su, Z.; Yang, S.; Wang, G.; Mi, W. Characteristics, formation and evolution of pre-salt dolomite reservoirs in the fifth member of the Ordovician Majiagou Formation, mid-east Ordos Basin, NW China. Pet. Explor. Dev. 2019, 46, 1153-1164. [CrossRef]

46. Zhang, X.; Zhang, T.; Lei, P.; Zhang, J.; Zhang, J.; Zhao, Z.; Yong, J. Origin and characteristics of grain dolomite of Ordovician Ma55 Member in the northwest of Ordos Basin, NW China. Pet. Explor. Dev. 2019, 46, 1115-1127. [CrossRef]

47. Zuo, M.; Hu, Z.; Zhang, C.; Hu, M.; Yang, W.; Mo, W. Control of differential tectonic activities on carbonate reservoirs in craton basin: A case study of the subsalt reservoir of Majiagou Formation in Ordos Basin. Geol. China. 2021, 48, 794-806.

48. Qiao, Y.; Zhang, L.; Wang, Y.; Zhang, Y.; Ma, J.; Jiang, H. Thrombolite types and seawater palaeosalinity of the 5th Member of Middle Ordovician Majiagou Formation in Sulige Gas Field, Ordos Basin. J. Palaeogeogr. Chin. Ed. 2020, 22, 97-110.

49. Xie, K.; Tan, X.; Feng, M.; Wang, B.; Zhong, S.; Yang, M.; Nie, W.; Qiao, Z.; Zeng, W. Eogenetic karst and its control on reservoirs in the Ordovician Majiagou Formation, eastern Sulige gas field, Ordos Basin, NW China. Pet. Explor. Dev. 2020, 47, $1246-1261$. [CrossRef]

50. Yang, W.; Wang, Q.; Liu, J.; Shi, K.; Wei, W. Standardization of sequence stratigraphy in Ordovician Majiagou formation, Ordos Basin. J. Xi'an Univ. Sci. Technol. 2017, 37, 234-241.

51. Popp, B.; Anderson, T.; Sandberg, P. Brachiopods as indicators of original isotopic composition in some Paleozoic limestones. Geol. Soc. Am. Bull. 1986, 97, 1262-1269. [CrossRef]

52. Lohmann, K.; Walker, J. The $\delta 18 \mathrm{O}$ record of Phanerozoic abiotic marine calcite cements. Geophys. Res. Lett. 1989, 16, 319-322. [CrossRef]

53. Burke, W.H.; Denison, R.E.; Hetherington, E.A.; Koepnick, R.B.; Nelson, H.F.; Otto, J.B. Variation of seawater 87Sr/86Sr throughout Phanerozoic time. Geology 1982, 10, 516-519. [CrossRef]

54. Veizer, J.; Ala, D.; Azmy, K.; Bruckschen, P.; Buhl, D.; Bruhn, F.; Carden, G.A.F.; Diener, A.; Ebneth, S.; Godderis, Y.; et al. 87Sr/86Sr, $\delta 13 \mathrm{C}$ and $\delta 18 \mathrm{O}$ evolution of Phanerozoic seawater. Chem. Geol. 1999, 161, 59-88. [CrossRef]

55. Shields, G.A.; Carden, G.A.F.; Veizer, J.; Meidla, T.; Rong, J.; Li, R. Sr, C, and O isotope geochemistry of Ordovician brachiopods: A major isotopic event around the Middle-Late Ordovician transition. Geochim. Cosmochim. Acta 2003, 67, 2005-2025. [CrossRef]

56. McLennan, S. Rare earth elements in sedimentary rocks: Influence of provenance and sedimentary processes. Rev. Mineral. Geochem. 1989, 21, 170-199.

57. McLennan, S. Relationships between the trace element composition of sedimentary rocks and upper continental crust. Geochem. Geophys. Geosyst. 2001, 2, 1021. [CrossRef] 
58. Coryell, C.; Chase, J.; Winchester, J. A procedure for geochemical interpretation of terrestrial rare-earth abundance pattern. J. Geophys. Res. 1963, 68, 559-566. [CrossRef]

59. Keith, M.L.; Anderson, G.M.; Eichler, R. Carbon and oxygen isotopic composition of mollusk shells from marine and fresh-water environments. Geochim. Cosmochim. Acta 1964, 28, 1757-1786. [CrossRef]

60. Keith, M.L.; Weber, J.N. Carbon and oxygen isotopic composition of selected limestones and fossils. Geochim. Cosmochim. Acta 1964, 28, 1787-1816. [CrossRef]

61. Bolhar, R.; Van Kranendonk, M. A non-marine depositional setting for the northern Fortescue Group, Pilbara Craton, inferred from trace element geochemistry of stromatolitic carbonates. Precambrian Res. 2007, 155, 229-250. [CrossRef]

62. Komiya, T.; Hirata, T.; Kitajima, K.; Yamamoto, S.; Shibuya, T.; Sawaki, Y.; Ishikawa, T.; Shu, D.; Li, Y.; Han, J. Evolution of the composition of seawater through geologic time, and its influence on the evolution of life. Gondwana Res. 2008, 14, 159-174. [CrossRef]

63. Ling, H.; Chen, X.; Li, D.; Wang, D.; Shields-Zhou, G.A.; Zhu, M. Cerium anomaly variations in Ediacaran-earliest Cambrian carbonates from the Yangtze Gorges area, South China: Implications for oxygenation of coeval shallow seawater. Precambrian Res. 2013, 225, 110-127. [CrossRef]

64. Bau, M.; Dulski, P. Distribution of yttrium and rare-earth elements in the Penge and Kuruman iron-formations, Transvaal Supergroup, South Africa. Precambrian Res. 1996, 79, 37-55. [CrossRef]

65. Alibert, C.; McCulloch, M.T. Rare earth element and neodymium isotopic compositions of the banded iron-formations and associated shales from Hamersley, western Australia. Geochim. Cosmochim. Acta 1993, 57, 187-204. [CrossRef]

66. German, C.; Elderfield, H. Application of the Ce Anomaly as a Paleoredox Indicator: The Ground Rules. Paleoceanography 1990, 5, 823-833. [CrossRef]

67. Michard, A.; Albarède, F. The REE content of some hydrothermal fluids. Chem. Geol. 1986, 55, 51-60. [CrossRef]

68. Robbins, L.J.; Lalonde, S.V.; Planavsky, N.J.; Partin, C.A.; Reinhard, C.T.; Kendall, B.; Scott, C.; Hardisty, D.S.; Gill, B.C.; Alessi, D.S.; et al. Trace elements at the intersection of marine biological and geochemical evolution. Earth-Sci. Rev. 2016, 163, 323-348. [CrossRef]

69. Adams, M. Dolomitization by Seepage Refluxion. AAPG Bull. 1960, 44, 1912-1920.

70. Dravis, J.; Wanless, H. Reflux dolomitization-A Holocene example beneath a coastal salina, West Caicos Island, Turks and Caicos Islands. Marine and Petroleum. Geology 2018, 97, 311-322.

71. Jiang, L.; Cai, C.; Worden, R.; Li, K.; Xiang, L. Reflux dolomitization of the Upper Permian Changxing Formation and the Lower Triassic Feixianguan Formation, NE Sichuan Basin, China. Geofluids 2013, 13, 232-245. [CrossRef] 